DO LEADING OR LAGGING FIRMS LEARN MORE FROM EXPORTING?

\author{
ROBERT SALOMON \\ Stern School of Business \\ New York University \\ 44 W. $4^{\text {th }}$ St., KMC 7-59 \\ New York, NY 10012 \\ Phone: 212-998-0223 \\ Fax: 212-995-4234 \\ E-mail: rsalomon@stern.nyu.edu
}

\author{
BYUNGCHAE JIN \\ Robert H. Smith School of Business \\ University of Maryland \\ Department of Management and Organization \\ 3330J Van Munching Hall \\ College Park, MD 20742 \\ Tel: 240-994-0216 \\ E-mail: bjin@rhsmith.umd.edu
}

Version: July 7, 2009 


\title{
DO LEADING OR LAGGING FIRMS LEARN MORE FROM EXPORTING?
}

\begin{abstract}
An interesting theoretical debate arises when considering firm heterogeneity in learning from exporting. One perspective intimates that technologically lagging firms stand to benefit more from exporting because exposure to technological knowledge in foreign markets allows these firms to close the gap with their more technologically endowed counterparts. A contrasting perspective posits that technologically superior firms benefit more from exporting since these firms are better equipped to translate knowledge acquired in foreign markets into innovation. Using a sample of 1,744 Spanish manufacturing firms from 1990-1997, this study empirically investigates how exporting differentially influences the patent output of technologically leading versus lagging firms. We find that exporting is associated with the ex post increase in innovative productivity for both technologically leading and lagging firms. However, subsequent to exporting, technologically leading firms apply for more patents than technologically lagging firms.
\end{abstract}

Keywords: organizational learning; learning from exporting; knowledge transfer; technological innovation; absorptive capacity 


\section{INTRODUCTION}

Early research in the field of international strategy demonstrates that advantageous assets and capabilities developed in the domestic market make it possible for firms to expand—and successfully compete—abroad (e.g., Buckley and Casson, 1976; Caves, 1971; Hymer, 1970, 1976; Morck and Yeung, 1991, 1992). More recently, scholars have suggested an alternative motivation for international expansion, arguing that since they can tap into valuable knowledge in the host country, firms may expand abroad in order to source, rather than simply exploit, knowledge (Cantwell, 1989; Ghoshal and Bartlett, 1990; Martin and Salomon, 2003). Consistent with said intuition, empirical evidence demonstrates that firms do indeed invest in other countries for the purpose of sourcing knowledge (e.g., Almeida, 1996; Cantwell, 1995; Kogut and Chang, 1991). Moreover, firms can use the knowledge they acquire in foreign markets to increase their ex post innovative productivity (Almeida, 1996; Penner-Hahn and Shaver, 2005).

Although the extant international strategy literature suggests that firms can learn from international expansion, prevailing research focuses almost exclusively on the benefits to firms that engage in foreign direct investment (FDI). We understand less about whether, and how, firms learn from other forms of international expansion such as exporting. Moreover, to the extent that such learning exists, we understand little about the conditions that moderate these effects. For example, it is unclear which firms are more likely to learn from exporting: technologically leading or lagging firms. We turn to the organizational learning and firm capability literatures to inform this debate.

One stream of literature in organizational learning supports the view that technologically lagging firms learn more from exporting than technologically leading firms 
because firms nearer to the technological frontier learn at a marginally decreasing rate (e.g., Argote, 1999; Dutton and Thomas, 1984; Yelle, 1979). This should enable technological laggards to close the capabilities gap with their technologically leading counterparts.

A stream of research in strategy, by contrast, suggests just the opposite. The firm capabilities literature maintains that firms are heterogeneous in the ability to learn (e.g., Cohen and Levinthal, 1990). To the extent that technological leaders possess capabilities that provide learning benefits, leaders might be able to accelerate their learning, and widen the capabilities divide separating them from their lagging counterparts.

The purpose of this study is to address this debate by examining how firm heterogeneity in technological capabilities moderates the relationship between exporting and innovation. In order to test these arguments, we examine the temporal relationship between exporting and innovation among 1,744 Spanish manufacturing firms from 19901997. We distinguish technologically leading firms from technologically lagging firms based upon relative $R \& D$ expenditures and then regress firm-level patent application counts on exporting across both sets of firms. We find that exporting is associated with the ex post increase in innovative productivity for both kinds of firms; however, subsequent to exporting, technological leaders apply for more patents than do technological laggards. We interpret this as evidence that technologically leading firms learn more from exporting.

The following section reviews the literatures on international expansion, organizational learning, firm capabilities, and learning from exporting to generate competing hypotheses. The subsequent sections describe the data, methods, and results. The final section discusses the findings and conclusions. 


\section{THEORY AND HYPOTHESES}

Early research in international business strategy sought to explain the existence, creation, and growth of the multinational enterprise (see Hymer, 1976; Vernon, 1966). Outcomes of those efforts suggest that, in order to succeed internationally, firms should possess advantageous intangible assets that they can leverage in a variety of foreign environments (Buckley and Casson, 1976; Hymer, 1976). Firms generally develop these advantages in the domestic market and then exploit them abroad (see Caves, 1996; Morck and Yeung, 1991, 1992).

Scholars have recently suggested an alternative inducement to engaging in FDI: Since firms can channel knowledge from the host country through their subsidiaries, firms may expand abroad to source, rather than simply exploit, knowledge (Cantwell, 1989; Ghoshal and Bartlett, 1990; Martin and Salomon, 2003). Empirical evidence suggests that firms do indeed invest abroad for the purpose of sourcing knowledge (e.g., Cantwell, 1989, 1995; Kogut and Chang, 1991). Moreover, firms can increase their innovative productivity as a result (Almeida, 1996; Penner-Hahn and Shaver, 2005).

Because early research focused predominantly on direct investment as an expansion strategy, we know relatively little from a strategic management perspective about exporting — despite the fact that it is the most prevalent form of international expansion (e.g., Salomon and Shaver, 2005b). ${ }^{1}$ However, a literature is beginning to emerge.

One relationship that has been noted across various studies—and countries—is that exporting firms tend to be more productive, ex ante, than non-exporting firms (e.g., Bernard and Jensen, 1999; Clerides, Lach, and Tybout, 1998; Delgado, Fariñas, and Ruano, 2002).

\footnotetext{
${ }^{1}$ For example, in the data we describe below, nearly half of the firms export, while less than $1 \%$ invest in foreign markets. Similarly, U.S. firms exported 1.63 trillion dollars of goods and services in 2007 while they increased FDI by only 353 billion dollars (U.S. BEA, 2008).
} 
Productivity advantages help firms to offset costs related to transportation and adapting products to the conditions of the host country market (Bernard and Jensen, 1999). Moreover, productivity advantages allow firms to compensate for country-specific disadvantages, and to compete more effectively with local firms (Salomon and Shaver, 2005a). These insights are generally consistent with findings from the literature on FDI.

However, of potentially greater strategic interest is if firms can also learn from exporting. Extant theory suggests that they ought to; and in fact, the mechanism by which firms learn by exporting is somewhat similar to how firms learn from foreign investment: both assume that foreign entry affords firms privileged access to information.

Grossman and Helpman (1991a, 1991b) argue that exporting tangible goods leads to the accumulation of intangible knowledge. This suggests that exporting firms, by interacting and competing in a foreign market, are exposed to knowledge that is unavailable to firms whose operations are confined to the domestic market.

Firms gain access to two types of knowledge via exporting: market knowledge and technological knowledge (Salomon and Shaver, 2005a). Market knowledge refers to the knowledge of customers, their preferences, and local customs (Afuah, 1998). Technological knowledge refers to the knowledge of operating processes, methods, and techniques - the scientific understanding of how, and why, things work (Rosenberg, 1982).

Expectedly, exporting firms receive a majority of the information that they use to improve from customers (Clerides et al., 1998). Consumer tastes and preferences vary by nation, and accordingly, the products consumers in the destination market desire often differ from those that the firm offers in its home country. Information received from foreign customers helps the firm tailor products to meet their specific needs (Vernon, 1966, 1979). 
In addition to the accumulation of market knowledge however, firms can also extend their technological knowledge through exporting. In this sense, learning reflects more than simply the modification of existing products to meet the needs of foreign consumers (Salomon and Shaver, 2005a; Salomon, 2006). Exporters learn about opportunities for new products and benefit from the technological expertise of their buyers (Clerides et al., 1998). Foreign buyers provide feedback on how to improve existing products, and they even offer technical, operational, and product development assistance toward that end (Evenson and Westphal, 1995).

Furthermore, exporting firms become connected within the host country, where they gain access to the local labor market, and the technical expertise of individuals in that market (Almeida, 1996). They can tap into local knowledge via trade associations and social engagements; and they benefit from the exchange of technical information among scientists, managers, engineers, and other industry professionals (Pack and Westphal, 1986; Rhee, Ross-Larsen, and Pursell, 1984). Exporters also encounter competitors in the host country that they do not face in the domestic market. They can therefore use host country competitors as an operational benchmark, and even reverse-engineer their products to gain technological insights (Salomon, 2006).

There is anecdotal support for these arguments. For example, Salomon and Shaver (2005a: 434) interviewed an export agent who described how agents often "take [exporters] to see the competition: their products, and sometimes their manufacturing process. That way [exporters] may be able to see where they stand vis-à-vis the market." Rhee et al. (1984) detail how Korean exporters were able to improve their production systems and the quality of their products as a direct result of the technical feedback they received from 
foreign buyers. Those authors explain how technological knowledge was shared among engineers and scientists who were party to formal, and informal, exchanges across firms. Similarly, Pack and Westphal (1986) found that exporters were able to steadily improve their technological capabilities over time via collaboration between foreign and local R\&D employees. This led Evenson and Westphal (1995: 2264) to conclude that "[a] good deal of the information needed to augment basic capabilities has come from the buyers of exports who freely provided product designs and offered technical assistance.” A study conducted by the World Bank (1997: 74) similarly concludes that "[p]articipating in export markets brings firms into contact with international best practices and fosters learning and productivity growth."

Although scholars have highlighted the potential for learning from exporting, only recently has the empirical literature begun to examine these relationships systematically. Initial efforts focused on whether a firm's total factor productivity increased after it began exporting, with conflicting results. Some authors find evidence for such improvement (e.g., Aw, Chung, and Roberts, 2000; Blalock and Gertler, 2004; Ozler and Yilmaz, 2001), while others do not (e.g., Bernard and Jensen, 1999; Clerides et al., 1998; Delgado et al., 2002).

More recent research suggests that the mixed empirical findings might be due to the use of total factor productivity as the dependent variable (e.g., MacGarvie, 2006; Salomon and Shaver, 2005a). These scholars argue that to evaluate whether firms have learned, a better measure would directly assess that learning outcome. A variety of factors influence the net effect of exporting on productivity, and it can be difficult to isolate the productivity impact. They propose that an analysis of innovation productivity, rather than total factor productivity, may capture more accurately the phenomenon of learning from exporting. 
Using innovative productivity as the dependent variable, Salomon and Shaver (2005a) find a consistent increase in innovation for firms after they begin to export. Specifically, exporters introduce more product innovations quickly after market entry, and file for significantly more patents several years after entry into export markets. The findings across both product and patent dependent variables not only provide evidence of a link between exporting and product modification, but they also suggest that firms benefit from access to technological knowledge. Salomon and Shaver (2005a) argue that market knowledge acquired via exporting leads firms to modify and tailor existing products (via product innovation). However, because technological knowledge lends itself to innovation in the form of patents (Afuah, 1998), the findings also demonstrate that exporting allows firms to amass technological information that spurs invention - and in ways that make them more innovative in their home markets. Corroborating and extending those findings, MacGarvie (2006) finds that exporting firms are more likely to cite foreign patents after they commence exporting. This implies that exporting is not simply spuriously related to an ex post increase in patent activity. Rather, firms use the technological knowledge that they acquire in export markets in a meaningful way.

Despite recent, and mounting, evidence that exporting firms gain a technological advantage over their purely domestic counterparts; interestingly, we understand little about how technological learning benefits vary across firms. Of particular interest to strategy and international business scholars is how firm heterogeneity in capabilities differentially impacts learning from exporting outcomes. Firms are not homogeneous in technological capabilities (Barney, 1991; Cohen and Levinthal, 1990; Henderson and Cockburn, 1996; Peteraf, 1993; Wernerfelt, 1984, 1995), and accordingly, one would expect variance in 
learning outcomes based on those capabilities. However, theory does not clearly suggest which firms ought to benefit more from exporting: those that are technologically inferior (lagging) or technologically superior (leading). There is literature to support both contradictory positions.

\section{Lagging firms learn more from exporting}

Rescorla and Wagner (1972) proposed an influential model of learning as a process that converges asymptotically to an absolute frontier, and where the rate of learning decreases as the learner approaches the frontier. In their model, learning is proportional to the distance between the frontier and the start point, with decreasing marginal returns. This is consistent with the theoretical treatment of, and empirical findings on, learning at the organizational level (for a review see Argote, 1999). Research demonstrates that learning converges to an asymptote, and diminishing marginal returns to learning have been well documented (Argote, 1999; Dutton and Thomas, 1984; Yelle, 1979). In addition, scholars find differences in learning rates within, and across, firms (Chew, Bresnahan, and Clark, 1990; Dutton and Thomas, 1984). Those authors highlight initial conditions, and the point at which firms find themselves in the learning curve, as factors underlying such differences.

If the technological productivity frontier is fixed and firms learn at a marginally decreasing rate as they approach the frontier, technologically lagging firms ought to learn at a faster rate than technologically leading firms. This reasoning has been used to motivate arguments addressing firm heterogeneity in learning from foreign investment (Blalock and

Gertler, 2009; Chung and Alcácer, 2002; Shaver and Flyer, 2000). For example, Chung and Alcácer (2002: 1535) suggest that technologically lagging firms can use their international 
investments to catch up to leading firms: "The conventional wisdom is that knowledge seeking occurs among technological laggards trying to reduce their gap . . . the more a firm's technical capabilities lag behind, the more likely the firm will be to seek technology." Similarly, Shaver and Flyer (2000: 1177) argue that "[t]he spillover of technology greatly enhances the competitiveness of the 'poor' technology firm yet does not (or only marginally) enhances the competitiveness of the 'good' technology firm." Blalock and Gertler (2009: 17-18) note that this is because "firms with poor initial technology are more likely to encounter new processes that yield high returns at low cost . . firms that have more room to improve relative to international best practice stand to reap the greatest marginal return from exposure to the new knowledge."

Although these studies were in the context of foreign investment, it is plausible that similar arguments extend to exporters, especially since it has been demonstrated that exporters benefit from some of the same technological benefits as firms that engage in FDI. Accordingly, exporting may provide technologically lagging firms exposure to relatively advanced knowledge in the destination market that yields technological insights that, in turn, help them innovate. By contrast, technologically leading firms — which are at, or near, the technological frontier - stand to learn less from exporting because the technological knowledge they encounter in the destination market is either already known to them, or it is inferior to that which they already possess.

Taken together, these arguments suggest that ex post innovation rates ought to be greater for technologically lagging exporters. We therefore hypothesize,

Hypothesis 1a: All else equal, technologically lagging firms will learn more from exporting than will technologically leading firms. 


\section{Leading firms learn more from exporting}

The firm capability perspective derives an alternative conclusion. Strategy scholars have long recognized that firm-specific capabilities are critical to a firm's success (Barney, 1991; Peteraf, 1993; Wernerfelt, 1984, 1995). Consistent with this conviction is empirical research showing that distinctive technological, marketing, and managerial capabilities can create value for firms (see Mahoney and Pandian, 1992, for a review). Moreover, when it comes to learning and innovation, technological capabilities play a central role. For example, in an empirical examination of the pharmaceutical industry, Henderson and Cockburn (1996) attribute a large proportion of the variance in innovative productivity to firm effects. They surmise that firm heterogeneity in technological capabilities explains differential learning and innovative productivity.

Cohen and Levinthal (1990) argue for a firm-specific technological capability they describe as "absorptive capacity." This construct captures "the ability of a firm to recognize the value of new external information, assimilate it, and apply it to commercial ends" (Cohen and Levinthal, 1990: 128). Absorptive capacity, therefore, confers upon a firm the ability to recognize the usefulness of external knowledge and use that knowledge to innovative ends. Moreover, according to Cohen and Levinthal (1990), absorptive capacity is a by-product of firm investments in R\&D.

Thus, while exporting increases the breadth—and potentially the flow—of technological knowledge to firms, the capabilities literature suggests that firms with strong technological capabilities are better positioned to use that knowledge to improve innovative productivity. Consistent with this conjecture are findings that demonstrate a connection between learning and investments in R\&D (Lieberman, 1984; Sinclair, Klepper, and 
Cohen, 2000). Moreover, Penner-Hahn and Shaver (2005) find similar effects in that technologically capable firms (those replete with absorptive capacity) innovate more in the years following foreign investment. They conclude that "the acquisition of skills and technologies is contingent on the investing firm possessing underlying technological capabilities..." (Penner-Hahn and Shaver, 2005: 122).

To the extent that technological leaders possess capabilities that provide learning benefits, leaders might be able to accelerate their learning, or shift the technological frontier outward via innovation (Lieberman, 1984; Penner-Hahn and Shaver, 2005; Sinclair et al., 2000; Vanneste and Puranam, 2009). Should that be the case, we might expect technological leaders to learn more from exporting than technological laggards, and to potentially widen the capabilities divide between them.

These arguments draw the opposite conclusion of those expressed in hypothesis 1a. Specifically, the view is that technological capabilities will positively moderate the relationship between exporting and innovation; and as such, ex post innovation rates should be greater for technologically leading exporters. Stated formally,

Hypothesis 1b: All else equal, technologically leading firms will learn more from exporting than will technologically lagging firms.

\section{DATA AND METHODS}

\section{Sample}

The primary data used in this study come from a yearly survey conducted by the Fundación Empresa Pública with the support of the Spanish Ministry of Industry. The Fundación surveys a sample of Spanish manufacturing firms in order to generate a 
representative picture of the country's manufacturing sector. The Fundación first

administered the survey in 1990, and we were able to get access to the data through 1997.

The data cover the entire population of Spanish manufacturing firms with 200 or

more employees and include a random sample of 5\% of the population of firms with fewer than 200 employees. The initial sample included information on 2,188 firms from 18 industries; however, to remain consistent with additional OECD data that we collected, we removed from the sample all firms classified as "Miscellaneous Manufacturing." This left an initial set of 2,137 firms from 17 industries. Table 1 presents the industry breakdown and some descriptives for the initial sample year.

\section{*** Insert Table 1 about here ***}

When a firm drops out of the sample in any given year, the Fundación replaces it with another of similar size from the same industry. Therefore, by 1997 , the 2,137 firms from the initial sample year grew to an unbalanced panel of 2,957 firms.

Based on an examination of the relevant data fields, and after discussions with representatives from the Fundación Empresa Pública, we removed 39 firms due to data recording errors. In addition, for 102 of the firms we were unable to come up with an exact industry match with the OECD data (see below). This reduced the sample to 2,816 firms.

Of these, we removed all 11 firms that reported engaging in FDI. ${ }^{2}$ For these firms there exist more direct mechanisms to facilitate information exchange from outside the

\footnotetext{
${ }^{2}$ Although Spanish firms in some sectors aggressively invested abroad in the 1990's, most of this investment was in the service sector (see Guillén, 2001, 2005). Spanish firms in the banking (notably BBV and Banco Santander), travel (e.g., Grupo Sol Melia), and telecommunications (Telefonica) industries were rather aggressive in investing abroad, especially in Latin America. However, Spanish firms are not nearly as strong globally in the manufacturing sector as in the service sector (Guillén, 2001, 2005). Because these data solely focus on manufacturing firms, our data do not capture this investment. For that reason, and because these data come from reliable government sources, we believe the level of FDI represented in these data is accurate although seemingly low; and when we include firms with foreign ownership in the analysis, we find results that are consistent with those presented.
} 
domestic market, and we do not want to spuriously attribute results from learning from FDI.

This left a sample of 2,805 firms. Because we have 8 years of Fundación data, the maximum number of firm-year observations in our analysis could have reached 22,440 (2,805 firms * 8 years of data). However, due to the unbalanced nature of the panel, those 2,805 firms account for only 13,268 observations (an average of 4.73 observations per firm).

To consider the temporal relationship between exporting and innovation, we incorporate dynamics in our empirical specification (the method is described in detail below). The dynamics require that there be no gaps in the within-firm time series. This restriction sacrifices 6,773 firm-year observations and 1,056 firms. ${ }^{3}$ An additional 51 observations (and 5 firms) were lost due to missing data. Our final usable sample therefore reduces to 6,444 firm-year observations from 1,744 firms. ${ }^{4}$

We complement the Fundación data with R\&D expenditure and gross production data from the OECD to identify whether a firm is a technological leader or laggard. The OECD publishes yearly R\&D figures in the ANBERD database. ANBERD contains information on industry-level R\&D expenditures from 27 countries (the 30 OECD member countries except for Austria, Luxembourg, and Switzerland). The OECD also publishes industry-level gross production data, which represent the market value of finished goods aggregated up to the industry level. The data are available for 22 countries (the 30 OECD member countries except for the Czech Republic, Hungary, Ireland, Luxembourg, Poland, the Slovak Republic, Switzerland, and Turkey).

\footnotetext{
${ }^{3}$ The dynamic specification that we use sacrifices the first three years worth of observations for every firm in our sample. We therefore lose any firm for which at least three years of continuous data are unavailable.

${ }^{4}$ Results were consistent with those presented herein when we exclude dynamics. Therefore, our specification, although it sacrifices some of the power of the sample, represents a more conservative test of the phenomenon.
} 


\section{Dependent variable}

Our dependent variable is innovative productivity. We proxy for innovative productivity using a count of patent applications. Researchers have used patent counts extensively to measure learning and innovative productivity (e.g., Basberg, 1982, 1987; Comanor and Scherer, 1969; Henderson and Cockburn, 1994, 1996; Scherer, 1965). Strengths and weaknesses of the measure have been well documented (Archibugi and Pianta, 1996; Cohen and Levin, 1989; Griliches, 1990; Hall, Jaffe, and Trajtenberg, 2001).

A firm seeking patent protection must apply to the agency that governs patenting in the country or region where it seeks protection. The European Patent Office (EPO), established as a result of the European Patent Convention (EPC) of Munich in October 1973, currently oversees and governs patent applications/grants in 19 European countries (EPO, 2000). Spain formally became a member of the EPC and aligned its national patent laws with prevailing European law on March 20, 1986 (Ulloa and Salas, 1993). However, it still maintains a national patent office. Thus, any firm seeking to patent technology in Spain has two options: to apply to the EPO, designating Spain as one of the countries where it seeks protection, or apply directly to the Spanish Industrial Property Registry (SIPR). The two offices use identical criteria for granting patents and offer the same protection to patent holders in Spain (Ulloa and Salas, 1993). It is more expensive to file with the EPO, and the process takes longer (an average of 18 months for the EPO, versus 12 with the SIPR). However, if a firm is applying for protection in more than one EPC country, applying through the EPO reduces paperwork and administrative costs (EPO, 2000).

The Fundación Empresa Pública collects information on the number of patents for which a focal firm applied in a given year. The variable we label PATENT 
APPLICATIONS captures the number of patent applications a firm filed for protection in Spain, whether via the SIPR or the EPO.

The variable we employ departs somewhat from existing research in that we measure total patent applications (regardless of whether they were granted) rather than those for patents that were later granted. As a result, it is likely that our variable upwardly approximates the number of patents that a firm ultimately receives. The EPO (2000) notes that European patent submissions have a $67 \%$ success rate, but since the Fundación does not identify the firms or patents by name, it is not possible to assess which applications were successful. A potential problem in assessing patent applications instead of only the patents granted is that this may capture spurious applications filed by the focal firm. However, because the application process is not costless, we expect that a firm would file only if it believed it has devised a legitimate innovation. Therefore, a benefit of this measure is that it captures the number of innovations for which the firm believes it is worth pursuing patent protection, while counts of applications that were ultimately granted may understate the number of innovations the firm achieved. ${ }^{5}$

\section{Independent variables}

Grossman and Helpman (1991b: 518) argue that exporting "tangible commodities facilitates the exchange of intangible ideas." As such, a measure of whether a firm has access to those ideas lies in whether or not it participates in export markets. The export status (EXPORT STATUS) of the firm was collected in the Fundación survey. This measure captures whether the focal firm sold to foreign markets in a given year. The variable

\footnotetext{
${ }^{5}$ The relationship between patent applications and R\&D in these data follow a similar pattern to that demonstrated between granted patents and R\&D found by Hausman, Hall, and Griliches (1984).
} 
EXPORT STATUS takes the value 1 if the firm exported in a given period, zero otherwise.

We complement the export status measure with one that captures the volume of trade. We do so because Grossman and Helpman (1991a) argue that the intensity of knowledge spillovers across two countries is likely to co-vary with the intensity of trade. We therefore define EXPORT VOLUME as the natural log of total export sales, expressed as thousands of Spanish pesetas plus one (so as to identify the measure for non-exporters).

Because knowledge takes time to filter back to the focal firm, the benefit of exporting may not be realized until future periods. Accordingly, we lag the export status and export volume variables. Based on the length of our panel and prior research, we use lags of one, two, and three years (Bernard and Jensen, 1999; Clerides et al., 1998; Salomon and Shaver, 2005a).

To identify whether a firm is a technological leader or laggard, we compare firms in these data to comparable others (in their industry) in the OECD on the basis of their R\&D expenditures. Research suggests that relative R\&D expenditures can proxy for a firm's technological capabilities (Caves, 1996; Chung and Alcácer, 2002; Cohen and Levinthal, 1990). R\&D expenditures are a correlate of knowledge stock, and therefore can be used to assess the technological capabilities of individual firms vis-à-vis the technological frontier (Chung and Alcácer, 2002; Porter, 1990).

We rely on industry-level R\&D expenditure and production data published by the OECD to make these comparisons. The R\&D expenditure data come from the ANBERD Database on Research and Development Expenditures. Expenditures are expressed in millions of purchasing power parity equivalent U.S. dollars. We complement the ANBERD 
data with OECD data on gross production by industry. ${ }^{6}$ Gross production data were expressed in the local country's national currency; however, we transformed them into U.S. dollars using OECD published purchasing power parity exchange rates. Both $R \& D$ expenditure and industry production data are reported at the four-digit ISIC industry level. Because the Fundación data are at the three-digit ISIC level, we recoded the original OECD data in accordance with the ISIC revision 3 (OECD, 2001) to match the three-digit ISIC industries in our data.

We develop two indices to discriminate technological leaders from technological laggards. The first measures the focal firm's relative R\&D intensity compared to the average industry R\&D expenditures in 21 OECD countries (other than Spain). This gauges the firm's technological standing relative to the average of other firms within the same industry from developed (OECD) countries. This captures the firm's proximity to the global technological frontier (Salomon and Jin, 2008).

We calculate this Research and Development Index (RDI) by scaling the R\&D expenditures of firm $i$ in industry $j$ at time $t$ by its sales at time $t$ to eliminate size effects. We similarly scale the R\&D expenditure in industry $j$ from country $k$ at time $t$ by its gross production (GP) in industry $j$ at time $t$. We average this R\&D/GP variable across all countries for which we have data (other than Spain) at time $t$. We then subtract the average R\&D expenditure (scaled by GP) in industry $j$ at time $t$ from the R\&D expenditures of firm $i$ from industry $j$ at time $t .^{7}$ This produces a time-varying, firm-specific index comparing the firms in these data to the average $R \& D$ expenditures from its corresponding industry in

\footnotetext{
${ }^{6}$ Because gross production captures the market value of finished goods within a given industry, it can be compared to sales at the firm level. It can be viewed as the aggregated, macro-equivalent of firm sales.

${ }^{7}$ We alternatively scaled the R\&D expenditures by GDP and population. Using GDP or population instead of gross production as the scaling factor yielded equivalent results.
} 
developed countries. Increasing values of the index indicate that a firm is a technological leader in its industry whereas decreasing values indicate that a firm is a technological laggard in its industry. This measure is consistent with prior empirical research (e.g., Benvignati, 1990; Chung and Alcácer, 2002; Kravis and Lipsey 1992; Salomon and Jin, 2008). Equation 1 expresses this measure formally:

$$
R D I_{i j t}^{O E C D}=R D_{i j t} / \text { Sales }_{i j t}-\left[\sum_{k=1}^{n}\left(R D_{j k t} / G P_{j k t}\right)\right] \times \frac{1}{n}
$$

where,

$$
\begin{aligned}
& R D I_{i j t}^{O E C D}: \text { R\&D Index for firm } i \text { from industry } j \text { in year } t \\
& R D_{i j t}: \text { R\&D expenditures of firm } i \text { from industry } j \text { in year } t \\
& \text { Sales }_{i j t}: \text { Total sales of firm } i \text { from industry } j \text { in year } t \\
& R D_{j k t}: \text { R\&D expenditures in industry } j \text { from country } k \text { in year } t \\
& G P_{j k t}: \text { Gross production in industry } j \text { from country } k \text { in year } t \\
& n: \text { Total number of OECD countries (21 nations, not including Spain). }
\end{aligned}
$$

Although the RDI ${ }^{O E C D}$ measure proxies for the technological capabilities of the focal firm vis-à-vis the global technological frontier (i.e., versus comparable firms in developed, OECD economies), it may inhere some bias to the extent that Spain is comparatively advantaged in given industries. We therefore complement our first RDI measure with a second that compares firms in these data to their industry average within Spain (as reported in ANBERD). This captures the firm's technological standing in its home country.

We calculate the second index similarly to how we calculate the first; however, instead of subtracting the OECD average R\&D expenditure from industry $j$ at time $t$, we subtract Spain's average R\&D expenditure (scaled by GP) from industry $j$ at time $t$ from the R\&D expenditure of firm $i$ from industry $j$ at time $t$. Again, increasing values of the index indicate that a firm is a technological leader in its industry, whereas decreasing values 
indicate that a firm is a technological laggard. Equation 2 expresses this formally:

$$
R D I_{i j t}^{\text {Spain }}=R D_{i j t} / \text { Sales }_{i j t}-R D_{j t}^{\text {Spain }} / G P_{j t}^{\text {Spain }}
$$

Calculating two distinct RDI measures provides several benefits for our purposes. Assessing both mitigates some of the deficiencies inherent in selecting one measure to the exclusion of the other. Moreover, because each variable might reveal different aspects of technological capabilities and technological leadership, we can use variation in outcomes to inform our interpretation of the results. Although we expect the results to be consistent across measures, corroborating results further validate to our findings.

We are interested in the moderating effects of RDI on the relationship between exporting and innovation. There are two general means to assess such moderation: using multiplicative interaction terms, or creating sub-sample splits based on the median or mean of the variable of interest (for a review, see Jaccard, Turrisi, and Wan, 1990). This study employs the latter technique, because interpreting interaction terms in non-linear regression formats is complicated by the underlying distribution of the dependent variable (in this case, Poisson). We therefore split the sample into two groups using the median of RDI. We consider firms above the median relative technological leaders, and those below the median relative technological laggards. We assess moderating effects by comparing the marginal effects of the coefficients across the two groups. ${ }^{8}$

*** Insert Table 2 about here***

Table 2 presents the medians and means of RDI across all industries in this study. The medians and means of $\mathrm{RDI}^{\text {Spain }}$ are relatively larger than those of $\mathrm{RDI}^{O E C D}$. This indicates that firms in the Fundación data are, on average, marginally technologically

\footnotetext{
${ }^{8}$ Similar results maintained when we conducted the sub-sample splits at the mean, at the quartiles, and at zero.
} 
superior to those in Spain, but technologically inferior to comparable firms in other OECD countries. That is, the firms in these data are technologically well-endowed domestic firms, but lag the global technological frontier. That Spanish firms lag the global technological frontier is consistent with the view of Spain as a developed, though middle-income, country (Campa and Guillén, 1999; Guillén, 2001, 2005). ${ }^{9}$

\section{Control variables}

Researchers have long considered the influence of firm size on innovative productivity (e.g., Schumpeter, 1942). Because exporters are generally larger than nonexporters, a reported effect of exports on innovation may spuriously capture the influence of size on innovation. We therefore control for firm size in order to diminish the potential for a size effect in these data. We define the variable SIZE as the natural log of total employees within the focal firm in a given year.

Scholars have similarly explored the influence of R\&D inputs on innovative productivity (for a review, see Cohen and Levin, 1989). We control for the effect of R\&D investments by including an R\&D intensity measure. We define R\&D INTENSITY as R\&D expenditures divided by total sales, expressed as a percentage.

Theories of firm-specific advantage suggest a link between a firm's intangible capabilities and its international business activity. Researchers typically proxy for such firm-level advantages using R\&D and advertising intensities (see e.g., Caves, 1996; Morck and Yeung, 1991, 1992). We therefore include advertising intensity, in addition to R\&D intensity, to measure a firm's marketing capabilities. We define ADVERTISING

\footnotetext{
${ }^{9}$ With respect to innovation, Spain ranks in the middle of the pack among OECD countries $\left(16^{\text {th }}\right.$ or $17^{\text {th }}$ out of 30 ), and $12^{\text {th }}$ among the 15 European Union members (prior to its 2004 expansion to 27 nations).
} 
INTENSITY as advertising expenditures divided by sales, expressed as a percentage.

Research in international management points out that FDI parents make trade-offs between autonomy and control (e.g., Birkinshaw and Hood, 1998; Kogut, 1983; Prahalad and Doz, 1987; Rangan, 1998). Foreign parents may allow subsidiaries to operate as freestanding units to respond to local market conditions; alternatively, they can integrate the multinational under one roof for operating efficiency. In order to control for how foreign ownership of the focal firm affects innovative productivity, we incorporate a measure of foreign capital participation (INWARD FDI). The variable is defined as the percentage of ownership foreign companies hold in the focal firm in a given year. ${ }^{10}$

Finally, to avoid erroneously attributing learning from importing to learning from exporting, we control for the influence of importing (MacGarvie, 2006). We define the variable IMPORT as 1 if the firm imported in a given period, zero otherwise. ${ }^{11,12}$

\section{Statistical method}

Our dependent variable is a count measure that can only take non-negative integer values. Moreover, many of the observations are bunched close to zero. Scholars suggest a Poisson regression model to deal with dependent count variables of this sort (Greene, 2003; Kennedy, 1998; Maddala, 1993). The Poisson regression, however, is quite sensitive to its distributional assumptions. Should the mean and variance for the observed sample not

\footnotetext{
${ }^{10}$ Again, since we excluded the 11 Spanish firms with outward FDI, we do not define a similar (OUTWARD FDI) variable for Spanish-owned companies with foreign subsidiaries.

${ }^{11}$ In contrast to our variable of interest, EXPORT, we do not lag the IMPORT variable. We include only contemporaneous import effects because examining learning from importing is outside the scope of the current study. In results not presented, we explored alternative model specifications in which we included import lags that match the export lags. The results on the variables of interest were consistent with those presented herein. Our inferences therefore do not change.

${ }^{12}$ We also explored models including import volume (contemporaneous and matching lags) in lieu of import status. Again, the results were consistent with those reported herein.
} 
equal lambda, the likelihood function would be misspecified leading standard errors to be underestimated and generating erroneous results. We found evidence of overdispersion in our data; therefore, we turn to a negative binomial model (Cameron and Trivedi, 1986; Hausman, Hall, and Griliches, 1984). Equation (3) formally expresses the specification:

$$
\lambda_{i t}=\exp \left(\beta_{1} x_{i, t-p}+\beta_{2} W_{i t}+\varepsilon_{i t}\right), \quad p=1,2,3
$$

where $\lambda_{\mathrm{it}}$ represents the expected number of innovations for firm $i$ at time $t, x_{\mathrm{i}, \mathrm{t}-\mathrm{p}}$ captures the exporting variable of interest for firm $i$ at time $t-p, \mathrm{~W}_{\mathrm{it}}$ is a vector of control variables, and $\varepsilon_{\mathrm{it}}$ is the individual unobserved error term. In the negative binomial model, $\varepsilon_{\mathrm{it}}$ is assumed to have a standard gamma distribution. The betas are parameter estimates.

Given the panel structure of our data with several observations per firm, the possibility arises that a systematic component may be embedded in $\varepsilon_{\mathrm{it}}$, leading to serial correlation of residuals across observations within firms and spurious regression results. Hausman et al. (1984) introduce a fixed-effect negative binomial model to control for serial correlation of this sort; however, there has been considerable debate about whether this method effectively controls for individual effects (Allison and Waterman, 2002).

We therefore turn to a dynamic longitudinal model to deal with serial correlation. We incorporate an INAR autoregressive process that includes lagged values of the dependent variable as regressors (see Alzaid and Al-Osh, 1990). ${ }^{13}$ Including firm dynamics provides three general benefits: First, it effectively reduces the potential for serial correlation of the errors; second, it allows for a dynamic firm-specific component, rather than the static

\footnotetext{
${ }^{13}$ For continuous dependent variables, the autoregressive model that includes exogenous regressors and lagged dependent variables has been proposed as a method of controlling for firm-specific effects (see Greene, 2003). Al-Osh and Alzaid (1987) and Brännäs and Hellström (2001) argue that the traditional AR(1) model can be extended to the integer-valued autoregressive (INAR(1)) model applied to count data. Moreover, Alzaid and Al-Osh (1990) refine an integer-valued $p$ th-order autoregressive structure (INAR(p)) process and address differences between the INAR(p) and AR(p) processes. We apply the INAR(p) process to our negative binomial model.
} 
nature of most fixed effects; and third, to the extent that previous values of the dependent variable are associated with a firm's propensity to export, it controls for the possible endogeneity of exporting (Cameron and Trivedi, 1998; Greene, 2003). Because we use three-year lags of the independent variable of interest (exporting), we incorporate three lags of the dependent variable into every specification. We estimate the following model:

$$
\lambda_{i t}=\exp \left(\rho_{1} y_{i, t-1}+\rho_{2} y_{i, t-2}+\rho_{3} y_{i, t-3}+\beta_{1} x_{i, t-p}+\beta_{2} W_{i t}+u_{i t}\right), \quad p=1,2,3
$$

where $y_{\mathrm{i}, t-1 \sim 3}$ are the lags of the dependent variable for firm $i$, and $\mathrm{u}_{\mathrm{it}}$ is an unobserved disturbance term that we can now more confidently assume is free of serial correlation. The rhos and betas represent coefficient estimates.

\section{RESULTS}

\section{Descriptive statistics and correlations}

Tables 3 and 4 present descriptive statistics and correlation matrices for the leader and laggard conditions split at the median of $\mathrm{RDI}^{O E C D}$ and $\mathrm{RDI}^{\text {Spain }}$, respectively. Not surprisingly, technologically leading firms are larger, spend more on advertising, and apply

for more patents. Likewise, consistent with broader findings on firm-specific advantage and international expansion, technologically leading firms (approximately 70\%) are more likely to be exporters than technologically lagging firms (approximately 40\%).

With respect to learning, we find positive correlations between the EXPORT STATUS/VOLUME lags and the dependent variable for both leaders and laggards, indicative of learning benefits associated with exporting. R\&D INTENSITY and ADVERTISING INTENSITY are positively correlated with innovative outcomes for both leaders and laggards. In addition, each of the EXPORT STATUS and EXPORT VOLUME 
lags is positively correlated with R\&D INTENSITY, ADVERTISING INTENSTITY, and SIZE. This suggests that exporting firms (both leading and lagging) spend more on R\&D and advertising, and are generally larger than non-exporting firms.

Although not reported, the $\mathrm{RDI}^{O E C D}$ and $\mathrm{RDI}^{\text {Spain }}$ measures are highly correlated $(\mathrm{r}=$ 0.82). This supports the view that the two are conceptually consistent. Moreover, the $\mathrm{RDI}^{O E C D}$ and $\mathrm{RDI}^{\text {Spain }}$ splits effectively discriminate technologically leading from technologically lagging firms. This is evident in the distribution of the R\&D INTENSITY variable across leader and laggard conditions. The mean R\&D INTENSITY from Table 3 is $1.60 \%$ for leaders and $0.01 \%$ for laggards. The means from Table 4 are $1.43 \%$ and $0.01 \%$, respectively. The range across both tables implies that there is little variance in $R \& D$ activity in the laggard condition, as lagging firms invest little in R\&D.

*** Insert Tables 3 and 4 about here $* * *$

Figures 1 and 2 compare the innovative activity of non-exporting firms to exporting firms in both the low-RDI and high-RDI conditions. Exporters (regardless of whether they are technological leaders or laggards) consistently have greater average patent application counts than their non-exporting counterparts. Moreover, the results illustrate a greater propensity to patent among technologically capable exporters (in the high-RDI condition). This relationship becomes pronounced in the latter years of the panel. While consistent with hypothesis $1 \mathrm{~b}$, we exercise caution in interpreting this effect. First, based on the patterns across the low- and high-RDI conditions, it is unclear whether the differences are statistically and/or economically meaningful. Second, this effect is solely illustrated contemporaneously; it does not assess if the direction of causality runs from innovation to exporting, vice versa, or both. Finally, it does not control for many other firm effects that 
we include in the multivariate analyses. Therefore, to better understand the nature of this relationship, we turn to the multivariate regression analyses.

$$
\text { ***Insert Figures } 1 \text { and } 2 \text { about here*** }
$$

\section{Regression results}

Table 5 presents the negative binomial regression results with export status as the independent variable of interest. Again, we present the results using median splits of $\mathrm{RDI}^{O E C D}$ in order to explore the moderating effects of technological leadership on the exporting-innovation relationship (Jaccard et al., 1990). We label firms below the RDI ${ }^{O E C D}$ median as "relative" technological laggards and firms above the median as "relative" technological leaders. Inherent in considering these firms as "relative" leaders or laggards is the assumption that such a split meaningfully captures the firms' proximity to the technological frontier. That is, the Spanish firms we characterize as "relative" technological leaders possess greater technological capabilities, and are closer to the technological frontier, than are those we consider as "relative" technological laggards. Therefore, we can plausibly expect to observe systematic variance in outcomes related to learning from exporting across conditions.

We control for unobserved firm heterogeneity by including an INAR (3) dynamic process into the model-i.e., incorporating three lags of the dependent variable. Although not reported, year dummies are also included to control for systematic time effects.

$$
\text { *** Insert Table } 5 \text { about here } * * *
$$

Columns 1 and 5 present base models with control variables only. For both sets of firms the one-year lag of patent applications has a positive and significant effect on current 
patent applications. This suggests that there is persistence in patent behavior-firms that applied for patents in the prior year are more likely to apply for patents in the current year. These effects expectedly diminish over time. The influence of current patent applications on future patent applications is strongest in the near term. SIZE is positive and significantly related to patent applications for technological leaders, but not significant for technological laggards, except in column 5. The results on ADVERTISING INTENSITY and R\&D INTENSITY are positive but not significant.

Given the systematic relationship between $R \& D$ and innovation demonstrated in the extant literature (e.g., Cohen and Levin, 1989; Cohen and Levinthal, 1990; Hausman et al., 1984), the non-significant coefficient for R\&D INTENSITY is somewhat surprising. There are, however, two effects likely masking the underlying relationship between R\&D and innovation in these data. First, the RDI sample split is likely driving a portion of the nonfinding. To the extent that RDI effectively discriminates leaders from laggards, firms within subsets might share more commonality in R\&D intensity. That is, there is greater variance on R\&D INTENSITY across conditions versus within conditions such that there is no residual impact of $R \& D$ within the subsamples. Second, the model specification likely explains another portion of the non-finding. Specifically, this study uses a conservative INAR (3) dynamic model, which includes three-year lags of the PATENT APPLICATIONS dependent variable. To the extent that prior years' patents predict patents in future years, prior patenting behavior more reliably explains the variance in patent applications than R\&D INTENSITY. ${ }^{14}$

With regard to tests of the hypotheses, we introduce one-, two-, and three-year lags

\footnotetext{
${ }^{14}$ Consistent with our conjecture, we found a positive and significant relationship between R\&D INTENSITY and PATENT APPLICATIONS when we pooled the sample. That relationship becomes stronger in models without dynamics. We thank an anonymous referee for motivating this robustness check.
} 
of the export status variable in columns $2,3,4,6,7$, and 8 . To determine whether there are statistically significant differences between the base models and the models including the lagged export variables, we employ the likelihood ratio test (Cameron and Trivedi, 1998). Likelihood ratio statistics comparing each export lag specification to the base case are at the bottom of the table. The differences in the log-likelihoods between the base models and all other models are statistically significant in every case $(p<.01$ for models 2,3 , and $4 ; p<.05$ for models 6 and 7; and $\mathrm{p}<.10$ for model 8). ${ }^{15}$ This suggests that each of the models including a lagged value of exporting more effectively accounts for a firm's innovative output than does the base model alone. The change in likelihood ratio is greatest for the three-year export status lag (column 4) for the technological leaders, and for the one-year export status lag (column 6) for the technological laggards. The specifications in columns 4 and 6 therefore best fit the data.

We find in all specifications in columns $2,3,4,6,7$, and 8 a positive and significant relationship between previous exporting and current innovation. These results are consistent with a main effect of exporting on innovation and suggest that exporting provides learning benefits for both technological leaders and laggards.

With respect to the moderating effects, the standard approach used to compare results across treatments is to compare coefficients via t-tests. However, a simple comparison of coefficients (t-tests) in a nonlinear maximum likelihood framework can cloud interpretation due to the inherent non-linearity of the underlying p.d.f. function, and the location on the curve at which the coefficients are estimated. Therefore, we compare marginal effects

\footnotetext{
${ }^{15}$ For example, in the case of columns 1 and 2 , the log likelihood test statistic is $6.978 \rightarrow-2 *((-1185.433)-(-$ 1181.944)). The p-value of this statistic (distributed Chi-square) is less than 0.01 .
} 
across conditions. ${ }^{16}$ We find that the marginal effects of export status on patent applications for technological leaders are consistently larger than they are for technological laggards. For example, for the one-year lag (EXPORT STATUS $\mathrm{t}_{\mathrm{t}-1}$ ), technological leaders gain an additional 0.05 of a patent $(0.07-0.02)$ from exporting. This finding supports hypothesis $1 \mathrm{~b}$. It implies a moderating effect of technological capabilities on the exporting-innovation relationship such that technological leaders learn more from exporting. *** Insert Table 6 about here***

We present results using export volume as an alternative to export status in table 6 . Overall patterns do not change. The results indicate that technological leaders benefit more from exporting than technological laggards. The difference in the marginal effect across the technological leader and laggard conditions are $0.01(0.01-0.00)$. This implies that for an equivalent level of export sales, technologically leading firms benefit from an additional 0.01 patent vis-à-vis technologically lagging firms.

***Insert Tables 7 and 8 about here $* * *$

Tables 7 and 8 re-estimate the results from tables 5 and 6 using the median split of the $\mathrm{RDI}^{\text {Spain }}$ variable. This provides another assessment of whether exporting leads to enhanced learning for technologically leading or lagging firms. The evidence across columns 2-4 and 5-7 in table 7 and columns 1-3 and 4-6 in table 8 corroborates our previous findings and confirms that technological leaders benefit more from exporting than do technological laggards. Taken together, the results from tables 5-8 reject hypothesis 1a in favor of hypothesis $1 b$.

\section{Additional results}

\footnotetext{
${ }^{16}$ The marginal effects represent the partial derivatives with respect to the mean of the variable in question.
} 
We performed one additional test to examine differential learning effects across leading/lagging firms. Tables 9 and 10 re-estimate the results splitting the sample at R\&D INTENSITY $=0$. We assign firms that invest in $R \& D$ to the relative leader condition and firms that do not invest in $R \& D$ to the relative laggard condition. ${ }^{17}$ This assesses whether findings using our method of discriminating leading from lagging firms (i.e., RDI) are also amenable to alternative approaches of discriminating leading from lagging firms (e.g., Blalock and Gertler, 2009; Cohen and Levinthal, 1990; Penner-Hahn and Shaver, 2005).

$$
\text { ***Insert Tables } 9 \text { and } 10 \text { about here*** }
$$

Again, the results across columns 2-4 and 5-7 in table 9 and columns 1-3 and 4-6 in table 10 corroborate previous findings. Leading firms (based on R\&D investments) learn more from exporting. Marginal effects for the export status measure suggest that we should expect technological leaders to benefit from an additional $0.06-0.07$ patent versus technological laggards. Similarly for export volume, a technological leader benefits from an additional 0.01 patent. Both sets of results support hypothesis $1 \mathrm{~b}$, as well as the theoretical mechanism that purportedly drives that effect.

\section{Sensitivity and robustness}

To assess the sensitivity and robustness of the results, we tested several variants of the models presented herein. ${ }^{18}$ First, our results could be biased to the extent that exporting is a sorting process whereby firms are matched with destination markets according to their technological capabilities. This would be the case if, for instance, technologically lagging firms export predominantly to developing countries, while technologically leading firms

\footnotetext{
${ }^{17}$ In these specifications we are unable to include R\&D INTENSITY as an explanatory variable because such models are not identified for the laggard condition.

${ }^{18}$ All results discussed in this section are available from the authors upon request.
} 
export predominantly to developed countries. If leading and lagging firms differ systematically in their destination markets in this manner, then the differences in learning across firms could simply reflect the different types of knowledge firms acquire in the destination market, rather than any true underlying heterogeneity across firms. To explore this possibility, we examined the variance in destination markets among the firms in these data. The Fundación Empresa Pública collects information on the breakdown of exports to OECD (developed) and Non-OECD (developing) countries. We found that Spanish firms export predominantly to OECD countries, irrespective of technological capabilities: OECD markets make up nearly $80 \%$ of the export volume for technological leaders and laggards alike. We then examined the impact of exporting to particular destination markets by splitting the sample into four separate conditions: OECD/Leaders; OECD/Laggards; NonOECD/Leaders; and Non-OECD/Laggards. We found that technologically leading firms that export predominantly to OECD countries learn more than do lagging firms that export predominantly to OECD countries. Likewise, leading firms that export predominantly to Non-OECD countries learn more than do lagging firms that export predominantly to NonOECD countries. These results are consistent with those presented in our study. Therefore, any bias inhered by destination market selection is likely to be small.

Second, our dynamic panel requires at least four years worth of patent data for each firm in the sample. This method provides some advantages in that it allows us to better infer directionality while accounting for reverse causality, endogeneity and/or unobserved heterogeneity that has the potential to bias our results. The disadvantage is that we sacrifice some power of the sample. To the extent that data restrictions bias our sample toward larger, more capable firms, and that the firms that are dropped from the sample systematically 
export and fail, our results may be subject to a survivor bias. We therefore tested variants of the specifications in which we eliminated the INAR (3) dynamics, decreased the lags, and in some instances, used only contemporaneous export effects. In all cases, the results were stronger in both statistical and economic magnitude than those presented.

Finally, not only do firms differ in their propensity to patent, but there is also substantial heterogeneity in patent behavior across industries (Archibugi and Pianta, 1996; Griliches, 1990). We attempt to control for that sort of industry heterogeneity through the disaggregated, firm-level INAR (3) dynamic effect. We favor this approach because firm variance on prior patent behavior subsumes industry variance. As such, controlling for firmspecific patenting behavior represents the more conservative test. Nevertheless, to ensure that our results were robust to the inclusion of industry, we ran results with industry dummies. The results were consistent with those presented in this study. We can therefore be more confident that our results capture the differential learning benefits across firmsand not simply patenting heterogeneity across industries.

\section{DISCUSSION AND CONCLUSION}

Although extant research highlights the potential for firms to learn from foreign investment, the empirical literature has only recently begun to suggest that firms can also learn from exporting. This study attempts to reconcile a theoretical debate about which firms are likely to benefit more from exporting — technological leaders or laggards.

We find that exporting provides both leading and lagging firms the opportunity to benefit from exposure to technological knowledge available in destination markets. However, results indicate that heterogeneity exists across firms in learning outcomes. 
Specifically, we find evidence that technological leaders learn more from exporting than do technological laggards, which supports the firm capabilities claim.

The outcomes of this study hold several important implications for both research and practice. First, for both technological leaders and laggards, we find that exporting increases the number of patent applications firms submit subsequent to exporting. This main effect of exporting on innovation is consistent with recent findings in the literature on learning from exporting (Aw et al., 2000; Blalock and Gertler, 2004; Ozler and Yilmaz, 2001; Salomon and Shaver, 2005a). Therefore, the present study corroborates existing evidence that demonstrates that exporting enables firms to learn.

Second, this paper contributes to the extant strategy and international business literatures by measuring and exploring the moderating effects of technological capabilities on the exporting-learning relationship. Our findings suggest that substantial heterogeneity exists across firms in learning outcomes and that technological leaders stand to benefit more from exporting. Although technological laggards do benefit from exporting, it does not enable them to close the gap with their technologically leading counterparts.

Third, these findings have implications for the literature on international expansion and firm performance. One of the basic premises of research on international expansion is that in order to succeed abroad, firms must possess some advantageous, intangible assets (Buckley and Casson, 1976; Hymer, 1976). In particular, that research highlights how international expansion creates value for firms with distinctive technological capabilities (for reviews, see Caves, 1996; Dunning, 1993; Morck and Yeung, 1991, 1992). The results from the present study are consistent with those from the broader international strategy literature, with one exception. Our results imply that not only are technologically endowed 
firms better suited to expand abroad, but that such an expansion allows those firms to reinforce, and build upon, their existing advantage.

The widening of the innovation gap between leaders and laggards holds insight for the organizational learning and capabilities literatures. As Helfat and Peteraf (2003: 1002) point out, "Relatively little empirical research... has confirmed or refuted the many theories of organizational learning, both in general and with regard to the development of organizational capabilities in particular." Our findings speak to one aspect of that debate. They suggest that technological capabilities are dynamic (Teece, Pisano, and Shuen, 1997); and that technologically capable firms possess a learning advantage that is self-reinforcing. Once established therefore, competitive heterogeneity of this sort is likely to persist for some time (Helfat and Peteraf, 2003).

Finally, our findings offer some practical implications for managers. They suggest that not all firms benefit from exporting equally. Managers should be aware that firms with existing technological capabilities are best positioned to benefit from knowledge spillovers. For technologically capable firms therefore, exporting can be considered a strategic action through which firms can enhance their competitive position. Moreover, learning from exporting provides value to firms beyond providing an outlet for selling existing products, and managers should learn to value those long-term benefits accordingly.

Although the outcomes of this research show promise for continued study and have implications for both scholars and practitioners, it is important to acknowledge several caveats. First, these findings are limited in context, since our study focuses solely on outcomes for technologically leading and lagging firms in Spain. Future research would be well served to explore whether similar results would be born out in other contexts. Second, 
this study examines learning from exporting. However, learning is an inherently complex construct. Although we have demonstrated evidence that is consistent with a learning interpretation, we cannot be sure that our results are a de facto outcome of learning. Third, although we would have liked to compare marginal effects across export status and export sales, we acknowledge that differences in scale make the comparison problematic. Future research would be well served to examine differences across export status and export sales to determine whether there are diminishing (or increasing) marginal returns to learning from exporting. Finally, although sensitivity analyses indicate that our results are robust to the relaxation of the INAR (3) sample restrictions, we cannot fully dismiss the possibility that a survivor bias has been inhered by this form of sample selectivity.

For these reasons, we are cautious to generalize our findings, and we acknowledge that further corroboratory research is needed before we can draw stronger conclusions. However, limitations notwithstanding, this study stands to make contributions to the fields of international business, strategy, and organizational learning. We hope that future research will refine, and extend, our contribution by examining improved data sets with finergrained measures. 


\section{REFERENCES}

Afuah A. 1998. Innovation Management: Strategies, Implementation, and Profits. Oxford University Press: New York.

Al-Osh MA, Alzaid AA. 1987. First order integer-valued autoregressive (INAR (1)) process. Journal of Time Series Analysis 8(3): 261-275.

Allison PD, Waterman RP. 2002 Fixed-effects negative binomial models. Sociological Methodology 32(1): 247-265.

Almeida P. 1996. Knowledge sourcing by foreign multinationals: patent citation analysis in the U.S. semiconductor industry. Strategic Management Journal, Winter Special Issue 17: 155-165.

Alzaid AA, Al-Osh MA. 1990. An integer-valued pth-order autoregressive structure (INAR (P)) process. Journal of Applied Probability 27(2): 314-324.

Archibugi D, Pianta M. 1996. Measuring technological change through patents and innovation surveys. Technovation 16(9): 451-467.

Argote, L. 1999. Organizational Learning: Creating, Retaining and Transferring Knowledge. Kluwer: Boston, MA.

Aw BY, Chung S, Roberts MJ. 2000. Productivity and turnover in the export market: micro evidence from Taiwan and South Korea. World Bank Economic Review 14(January): 65-90.

Barney JB. 1991. Firm resources and sustained competitive advantage. Journal of Management 17(1): 99-120.

Basberg BL. 1982. Technological change in the Norwegian whaling industry: a case study in the use of patent statistics as a technology indicator. Research Policy 11(3): 163-171.

Basberg BL. 1987. Patents and the measurement of technological change: a survey of the literature. Research Policy 16(2-4): 131-141.

Benvignati AM. 1990. Industry determinants and "differences" in U.S. intrafirm and armslength exports. Review of Economics and Statistics 72(3): 481-488.

Bernard AB, Jensen JB. 1999. Exceptional exporter performance: cause, effect, or both? Journal of International Economics 47(1): 1-25.

Birkinshaw J, Hood N. 1998. Multinational subsidiary evolution: capability and charter change in foreign-owned subsidiary companies. Academy of Management Review 23(4): 773-795.

Blalock G, Gertler PJ. 2004. Learning from exporting revisited in a less developed setting. Journal of Development Economics 75(2): 397-416.

Blalock G, Gertler PJ. 2009. How firm capabilities affect who benefits from foreign technology. Forthcoming in Journal of Development Economics.

Brännäs K, Hellström J. 2001. Generalized integer-valued autoregression. Econometric Reviews 20(4): 425-443.

Buckley PJ, Casson M. 1976. The Future of the Multinational Enterprise. Holmes \& Meier: London, UK. 
Cameron AC, Trivedi PK. 1986. Econometric models based on count data: comparisons and applications of some estimators and tests. Journal of Applied Econometrics 1(1): 29-54.

Cameron AC, Trivedi PK. 1998. Regression Analysis of Count Data. Cambridge University Press: New York.

Campa JM, Guillén MF. 1999. The internalization of exports: firm- and location-specific factors in a middle-income country. Management Science 45(11): 1463-1478.

Cantwell JA. 1989. Technological Innovation and Multinational Corporations. Basil Blackwell: Oxford, UK.

Cantwell JA. 1995. The globalisation of technology: what remains of the product cycle model? Cambridge Journal of Economics 19(1): 155-174.

Caves RE. 1971. International corporations: The industrial economics of foreign investment. Economica 38(149): 1-27.

Caves RE. 1996. Multinational Enterprise and Economic Analysis (2nd edn). Cambridge University Press: Cambridge.

Chew WB, Bresnahan TF, Clark KB. 1990. Measurement, coordination, and learning in a multiplant network. In Measures for Manufacturing Excellence, Kaplan RS (ed). Harvard Business School Press: Boston, MA: 129-162.

Chung W, Alcácer J. 2002. Knowledge seeking and location choice of foreign direct investment in the United States. Management Science 48(12): 1534-1554.

Clerides SK, Lach S, Tybout JR. 1998. Is learning by exporting important? micro-dynamic evidence from Columbia, Mexico, and Morocco. Quarterly Journal of Economics 113(3): 903-947.

Cohen WM, Levin RC. 1989. Empirical studies of innovation and market structure. In Handbook of Industrial Organization, Schmalensee R, Willig RD (eds). North-Holland: New York: 1059-1107.

Cohen WM, Levinthal DA. 1990. Absorptive capacity: a new perspective on learning and innovation. Administrative Science Quarterly 35(1): 128-152.

Comanor WS, Scherer FM. 1969. Patent statistics as a measure of technical change. Journal of Political Economy 77(3): 392-398.

Delgado MA, Fariñas JC, Ruano S. 2002. Firm productivity and export markets: a nonparametric approach. Journal of International Economics 57(2): 397-422.

Dunning JH. 1993. Multinational Enterprises and the Global Economy. Addison-Wesley: Reading, MA.

Dutton JM, Thomas A. 1984. Treating progress functions as a managerial opportunity. Academy of Management Review 9(2): 235-247.

European Patent Office. 2000. Facts and Figures.

Evenson RE, Westphal LE. 1995. Technological change and technology strategy. In Handbook of Development Economics, Behrman J, Srinivasan TN (eds). North-Holland: New York: 2211-2299. 
Ghoshal S, Bartlett CA. 1990. The multinational corporation as an interorganizational network. Academy of Management Review 15(4): 603-625.

Greene WH. 2003. Econometric Analysis (5th edn). Prentice Hall: Upper Saddle River, NJ. Griliches Z. 1990. Patent statistics as economic indicators: a survey. Journal of Economic Literature 28(4): 1661-1797.

Grossman GM, Helpman E. 1991a. Innovation and Growth in the Global Economy. MIT Press: Cambridge, MA.

Grossman GM, Helpman E. 1991b. Trade, knowledge spillovers, and growth. European Economic Review 35(3): 517-526.

Guillén MF. 2001. The Limits of Convergence: Globalization and Organizational Change in Argentina, South Korea, and Spain. Princeton University Press: Princeton, NJ.

Guillén MF. 2005. The Rise of Spanish Multinationals. Cambridge University Press:

Cambridge, UK.

Hall BH, Jaffe AB, Trajtenberg M. 2001. The NBER patent citations data file: lessons insights and methodological tools. NBER working paper \#8498.

Hausman JA, Hall BH, Griliches Z. 1984 Econometric models for count data with an application to the patents-R\&D relationship. Econometrica 52(4): 909-938.

Helfat CE, Peteraf MA. 2003. The dynamic resource-based view: capability lifecycles. Strategic Management Journal 24(10): 997-1010.

Henderson R, Cockburn I. 1994. Measuring competence? exploring firm effects in pharmaceutical research. Strategic Management Journal, Winter Special Issue 15: 63-84.

Henderson R, Cockburn I. 1996. Scale, scope, and spillovers: the determinants of research productivity in drug discovery. Rand Journal of Economics 27(1): 32-60.

Hymer SH. 1970. The efficiency (contradictions) of multinational corporations. American Economic Review 60(2): 441-448.

Hymer SH. 1976. The International Operations of National Firms: A Study of Direct Foreign Investment. MIT Press: Cambridge, MA.

Jaccard J, Turrisi R, Wan CK. 1990. Interaction Effects in Multiple Regression. Sage: Newbury Park, CA.

Kennedy P. 1998. A Guide to Econometrics (4th edn). The MIT Press: Cambridge, MA.

Kogut B, Chang SJ. 1991. Technological capabilities and Japanese foreign direct investment in the United States. Review of Economics and Statistics 73(3): 401-413.

Kogut B. 1983. Foreign direct investment as a sequential process. In The Multinational Corporation in the 1980s, Kindleberger CP, Audretsch DB (eds). MIT Press: Cambridge, MA: 38-56.

Kravis I, Lipsey R. 1992. Sources of competitiveness of the United States and of its multinational firms. Review of Economics and Statistics 74(2): 193-201.

Lieberman MB. 1984. The learning curve and pricing in the chemical processing industries. 
Rand Journal of Economics 15(2): 213-228.

MacGarvie M. 2006. Do firms learn from international trade? Review of Economics and Statistics 88(1): 46-60.

Maddala GS. 1993. Limited Dependent and Qualitative Variables in Econometrics. Cambridge University Press: Cambridge, UK.

Mahoney JT, Pandian JR. 1992. The resource-based view within the conversation of strategic management. Strategic Management Journal 13(5): 363-380.

Martin X, Salomon R. 2003. Knowledge transfer capacity and its implications for the theory of the multinational corporation. Journal of International Business Studies 34(4): 356-373.

Morck R, Yeung B. 1991. Why investors value multinationality. Journal of Business 64(2): 165-187.

Morck R, Yeung B. 1992. Internalization: an event study test. Journal of International Economics 33(1-2): 41-56.

OECD. 2001. Research and Development Expenditure in Industry, 1987-1999. OECD Publication Service: Paris, France.

Ozler S, Yilmaz K. 2001, Does trade liberalization improve productivity? plant level evidence from the Turkish manufacturing industry. Working Paper, University of California, Los Angeles.

Pack H, Westphal LE. 1986. Industrial strategy and technological change: theory versus reality. Journal of Development Economics 22(1): 87-128.

Penner-Hahn J, Shaver JM. 2005. Does international research and development increase patent output? an analysis of Japanese pharmaceutical firms. Strategic Management Journal 26(2): 121-140.

Peteraf MA. 1993. The cornerstones of competitive advantage: a resources-based view. Strategic Management Journal 14(3): 179-191.

Porter ME. 1990. The Competitive Advantage of Nations. Free Press: New York.

Prahalad CK, Doz YL. 1987. The Multinational Mission: Balancing Local Demands and Global Vision. Free Press: New York.

Rangan S. 1998. Do multinationals operate flexibly? theory and evidence. Journal of International Business Studies 29(2): 217-237.

Rescorla RA, Wagner AR. 1972. A theory of Pavlovian conditioning: variations in the effectiveness of reinforcement and non-reinforcement. In Classical Conditioning II, Black AH, Prokasy WF (eds). Appleton-Century-Crofts: New York: 64-99.

Rhee YW, Ross-Larsen B, Pursell G. 1984. Korea's Competitive Edge: Managing the Entry into World Markets. Johns Hopkins University Press: Baltimore, MD.

Rosenberg N. 1982. Inside the Black Box: Technology and Economics. Cambridge University Press: New York.

Salomon R, Jin B. 2008. Does knowledge spill to leaders or laggards? exploring industry 
heterogeneity in learning by exporting. Journal of International Business Studies 39(1): $132-150$.

Salomon R, Shaver JM. 2005a. Learning by exporting: new insights from examining firm innovation. Journal of Economics and Management Strategy 14(2): 431-460.

Salomon R, Shaver JM. 2005b. Export and domestic sales: their interrelationship and determinants. Strategic Management Journal 26(9): 855-871.

Salomon R. 2006. Spillovers to foreign market participants: assessing the impact of export strategies on innovative productivity. Strategic Organization 4(2): 135-164.

Scherer FM. 1965. Firm size, market structure, opportunity and the output of patented inventions. American Economic Review 55(5): 1097-1125.

Schumpeter JA. 1942. Capitalism, Socialism, and Democracy. Harper and Brothers: New York.

Shaver JM, Flyer F. 2000. Agglomeration economies, firm heterogeneity, and foreign direct investment in the United States. Strategic Management Journal 21(12): 1175-1193.

Sinclair G, Klepper S, Cohen W. 2000. What's experience got to do with it? sources of cost reduction in a large specialty chemicals producer. Management Science 46(1): 28-45.

Teece DJ, Pisano G, Shuen A. 1997. Dynamic capabilities and strategic management. Strategic Management Journal 18(7): 509-533.

U.S. BEA. 2008. U.S. international transactions: fourth quarter and year 2007 current account. Press release (17 March 2008), http://www.bea.doc.gov.

Ulloa G, Salas E. 1993. The Basic Features of Spain's Patents and Models. Patent Yearbook.

Vanneste BS, Puranam P. 2009. Repeated interactions and contractual detail: identifying the learning effect. Forthcoming in Organization Science.

Vernon R. 1966. International investment and international trade in the product cycle. Quarterly Journal of Economics 80(2): 190-207.

Vernon R. 1979. The product cycle hypothesis in a new international environment. Oxford Bulletin of Economics and Statistics 41(4): 255-268.

Wernerfelt B. 1984. A resource-based view of the firm. Strategic Management Journal 5(2): 171-180.

Wernerfelt B. 1995. The resource-based view of the firm: ten years after. Strategic Management Journal 16(3): 171-174.

World Bank. 1997. World Development Report: The State in a Changing World. Oxford University Press: New York.

Yelle LE. 1979. The learning curve: historical review and comprehensive survey. Decision Science 10(2): 302-328. 
Table 1. Industry breakdown of the sample (Year =1990)

\begin{tabular}{lccccc}
\hline \multicolumn{1}{c}{ Industry } & $\begin{array}{c}\text { Number of } \\
\text { Firms }\end{array}$ & $\begin{array}{c}\text { Percentage } \\
\text { of Total } \\
(\%)\end{array}$ & $\begin{array}{c}\text { Employees } \\
\text { per firm }\end{array}$ & $\begin{array}{c}\text { Avg. Sales } \\
\text { (Billion Pts.) }\end{array}$ & $\begin{array}{c}\text { Exports as a } \\
\text { percentage of } \\
\text { total sales } \\
(\%)\end{array}$ \\
\hline 1. Ferrous and non-ferrous metals & 45 & 2.11 & 753.75 & 2.10 & 35.63 \\
2. Non-metallic products & 161 & 7.53 & 181.08 & 0.32 & 18.33 \\
3. Chemical products & 149 & 6.97 & 323.84 & 1.02 & 23.50 \\
4. Metallurgy and metallic products & 223 & 10.44 & 120.18 & 0.18 & 27.16 \\
5. Agricultural machinery & 125 & 5.85 & 186.20 & 0.27 & 35.00 \\
6. Office products and data processing & 22 & 1.03 & 512.84 & 2.27 & 32.10 \\
7. Electrical accessories and materials & 201 & 9.41 & 316.24 & 0.61 & 25.88 \\
8. Automobiles and motors & 81 & 3.79 & 952.17 & 3.12 & 49.04 \\
9. Transport material & 54 & 2.53 & 768.69 & 0.93 & 56.40 \\
10. Meat products & 59 & 2.76 & 198.73 & 0.52 & 6.06 \\
11. Food and tobacco & 229 & 10.72 & 242.91 & 0.92 & 5.70 \\
12. Beverages & 53 & 2.48 & 352.36 & 1.05 & 5.55 \\
13. Textiles and clothing & 249 & 11.65 & 149.17 & 0.16 & 20.02 \\
14. Leather and footwear & 76 & 3.56 & 50.81 & 0.07 & 40.83 \\
15. Wood and wood products & 146 & 6.83 & 44.88 & 0.06 & 10.35 \\
16. Paper and publishing & 163 & 7.63 & 164.80 & 0.35 & 22.34 \\
17. Rubber and plastic products & 101 & 4.73 & 144.46 & 0.24 & 30.23 \\
\hline \multicolumn{1}{c}{ Total } & 2137 & 100.00 & 321.36 & 0.83 & 31.66 \\
\hline
\end{tabular}


Table 2. Medians and means of RDI by industry

\begin{tabular}{lcccc}
\hline \multicolumn{1}{c}{ Industry } & $\begin{array}{c}\mathrm{RDI}^{\text {Spain }} \\
\text { Mean }\end{array}$ & $\begin{array}{c}\mathrm{RDI}^{\text {Spain }} \\
\text { Median }\end{array}$ & $\begin{array}{c}\mathrm{RDI}^{\mathrm{OECD}} \\
\text { Mean }\end{array}$ & $\begin{array}{c}\mathrm{RDI}^{\mathrm{OECD}} \\
\text { Median }\end{array}$ \\
\hline 1. Ferrous and non-ferrous metals & 0.004 & 0.001 & -0.001 & -0.004 \\
2. Non-metallic products & 0.003 & -0.000 & -0.001 & -0.004 \\
3. Chemical products & 0.021 & 0.007 & 0.006 & -0.008 \\
4. Metallurgy and metallic products & 0.004 & -0.000 & 0.003 & -0.001 \\
5. Agricultural machinery & 0.014 & -0.000 & -0.000 & -0.012 \\
6. Office products and data processing & 0.017 & 0.009 & -0.026 & -0.034 \\
7. Electrical accessories and materials & 0.014 & 0.001 & -0.029 & -0.041 \\
8. Automobiles and motors & 0.011 & 0.004 & -0.007 & -0.014 \\
9. Transport material & 0.014 & -0.000 & -0.017 & -0.031 \\
10. Meat products & 0.001 & -0.000 & -0.001 & -0.002 \\
11. Food and tobacco & 0.002 & -0.000 & -0.000 & -0.002 \\
12. Beverages & 0.002 & -0.000 & -0.000 & -0.002 \\
13. Textiles and clothing & 0.004 & -0.000 & 0.002 & -0.002 \\
14. Leather and footwear & 0.004 & -0.000 & 0.003 & -0.001 \\
15. Wood and wood products & 0.001 & -0.000 & -0.001 & -0.002 \\
16. Paper and publishing & 0.003 & -0.000 & 0.001 & -0.001 \\
17. Rubber and plastic products & 0.004 & -0.000 & -0.001 & -0.005 \\
\hline
\end{tabular}


Table 3. Descriptive statistics and correlations (split by RDI ${ }^{O E C D}$ )

\begin{tabular}{|c|c|c|c|c|c|c|c|c|c|c|c|c|c|c|c|c|c|c|}
\hline Variable & Mean & S.D. & Min & Max & 1 & 2 & 3 & 4 & 5 & 6 & 7 & 8 & 9 & 10 & 11 & 12 & 13 & 14 \\
\hline \multicolumn{19}{|l|}{ Leaders $(N=2474)$ : } \\
\hline 1. Patent applications $(\mathrm{t})$ & 0.36 & 1.49 & 0.00 & 19.00 & 1.00 & & & & & & & & & & & & & \\
\hline 2. Patent applications $(\mathrm{t}-1)$ & 0.45 & 2.71 & 0.00 & 92.00 & 0.38 & 1.00 & & & & & & & & & & & & \\
\hline 3. Patent applications $(\mathrm{t}-2)$ & 0.44 & 2.60 & 0.00 & 92.00 & 0.35 & 0.32 & 1.00 & & & & & & & & & & & \\
\hline 4. Patent applications $(\mathrm{t}-3)$ & 0.42 & 2.46 & 0.00 & 92.00 & 0.30 & 0.19 & 0.23 & 1.00 & & & & & & & & & & \\
\hline 5. Export status $_{(\mathrm{t}-1)}$ & 0.73 & 0.44 & 0.00 & 1.00 & 0.07 & 0.06 & 0.06 & 0.08 & 1.00 & & & & & & & & & \\
\hline 6. Export status $(\mathrm{t}-2)$ & 0.72 & 0.45 & 0.00 & 1.00 & 0.07 & 0.06 & 0.06 & 0.07 & 0.88 & 1.00 & & & & & & & & \\
\hline 7. Export status $(\mathrm{t}-3)$ & 0.71 & 0.46 & 0.00 & 1.00 & 0.07 & 0.05 & 0.04 & 0.07 & 0.81 & 0.86 & 1.00 & & & & & & & \\
\hline 8. Export volume $(\mathrm{t}-1)$ & 9.69 & 6.16 & 0.00 & 19.74 & 0.07 & 0.06 & 0.06 & 0.08 & 0.95 & 0.87 & 0.82 & 1.00 & & & & & & \\
\hline 9. Export volume $(\mathrm{t}-2)$ & 9.43 & 6.18 & 0.00 & 19.74 & 0.08 & 0.05 & 0.06 & 0.08 & 0.85 & 0.95 & 0.86 & 0.93 & 1.00 & & & & & \\
\hline 10. Export volume $(\mathrm{t}-3)$ & 9.16 & 6.21 & 0.00 & 19.74 & 0.08 & 0.06 & 0.05 & 0.08 & 0.79 & 0.84 & 0.95 & 0.88 & 0.92 & 1.00 & & & & \\
\hline 11. $\mathrm{R} \& \mathrm{D}$ intensity $(\mathrm{t})$ & 1.60 & 2.82 & 0.00 & 27.20 & 0.11 & 0.09 & 0.08 & 0.10 & 0.14 & 0.12 & 0.12 & 0.13 & 0.12 & 0.12 & 1.00 & & & \\
\hline 12. Advertising intensity $(\mathrm{t})$ & 2.05 & 3.83 & 0.00 & 44.90 & 0.08 & 0.04 & 0.05 & 0.04 & 0.17 & 0.18 & 0.18 & 0.15 & 0.15 & 0.14 & 0.08 & 1.00 & & \\
\hline 13. Size $_{(t)}$ & 4.99 & 1.57 & 0.00 & 10.02 & 0.12 & 0.07 & 0.07 & 0.08 & 0.52 & 0.53 & 0.53 & 0.66 & 0.67 & 0.66 & 0.14 & 0.16 & 1.00 & \\
\hline 14. Inward FDI $(\mathrm{t})$ & 26.42 & 41.44 & 0.00 & 100.00 & -0.03 & -0.02 & 0.00 & -0.02 & 0.30 & 0.29 & 0.29 & 0.37 & 0.37 & 0.35 & 0.01 & 0.07 & 0.42 & 1.00 \\
\hline 15. $\operatorname{Import}_{(\mathrm{t})}$ & 0.77 & 0.42 & 0.00 & 1.00 & 0.11 & 0.08 & 0.08 & 0.08 & 0.56 & 0.55 & 0.53 & 0.59 & 0.58 & 0.56 & 0.18 & 0.15 & 0.57 & 0.31 \\
\hline \multicolumn{19}{|l|}{ Laggards $(N=3970)$ : } \\
\hline 1. Patent applications $(\mathrm{t})$ & 0.06 & 0.62 & 0.00 & 24.00 & 1.00 & & & & & & & & & & & & & \\
\hline 2. Patent applications $(\mathrm{t}-1)$ & 0.07 & 0.74 & 0.00 & 24.00 & 0.59 & 1.00 & & & & & & & & & & & & \\
\hline 3. Patent applications $(\mathrm{t}-2)$ & 0.09 & 0.97 & 0.00 & 36.00 & 0.49 & 0.58 & 1.00 & & & & & & & & & & & \\
\hline 4. Patent applications $(\mathrm{t}-3)$ & 0.13 & 1.37 & 0.00 & 43.00 & 0.27 & 0.38 & 0.58 & 1.00 & & & & & & & & & & \\
\hline 5. Export status $(\mathrm{t}-1)$ & 0.44 & 0.50 & 0.00 & 1.00 & 0.04 & 0.05 & 0.06 & 0.06 & 1.00 & & & & & & & & & \\
\hline 6. Export status $(\mathrm{t}-2)$ & 0.41 & 0.49 & 0.00 & 1.00 & 0.04 & 0.04 & 0.06 & 0.07 & 0.84 & 1.00 & & & & & & & & \\
\hline 7. Export status $(\mathrm{t}-3)$ & 0.39 & 0.49 & 0.00 & 1.00 & 0.06 & 0.06 & 0.07 & 0.07 & 0.76 & 0.83 & 1.00 & & & & & & & \\
\hline 8. Export volume $(\mathrm{t}-1)$ & 5.13 & 6.09 & 0.00 & 19.96 & 0.05 & 0.06 & 0.06 & 0.06 & 0.96 & 0.85 & 0.80 & 1.00 & & & & & & \\
\hline 9. Export volume $(\mathrm{t}-2)$ & 4.83 & 6.01 & 0.00 & 19.89 & 0.04 & 0.05 & 0.07 & 0.07 & 0.83 & 0.96 & 0.85 & 0.91 & 1.00 & & & & & \\
\hline 10. Export volume $(\mathrm{t}-3)$ & 4.59 & 5.94 & 0.00 & 19.75 & 0.06 & 0.06 & 0.07 & 0.07 & 0.77 & 0.83 & 0.96 & 0.85 & 0.90 & 1.00 & & & & \\
\hline 11. $R \& D$ intensity $(t)$ & 0.01 & 0.07 & 0.00 & 0.70 & 0.02 & 0.02 & 0.03 & 0.07 & 0.17 & 0.18 & 0.18 & 0.23 & 0.23 & 0.23 & 1.00 & & & \\
\hline 12. Advertising intensity $(\mathrm{t})$ & 0.97 & 2.36 & 0.00 & 41.00 & 0.03 & 0.04 & 0.02 & 0.02 & 0.16 & 0.16 & 0.16 & 0.18 & 0.17 & 0.17 & 0.04 & 1.00 & & \\
\hline 13. $\operatorname{Size}_{(\mathrm{t})}$ & 3.69 & 1.36 & 0.00 & 9.53 & 0.05 & 0.07 & 0.05 & 0.03 & 0.48 & 0.48 & 0.48 & 0.60 & 0.59 & 0.59 & 0.22 & 0.22 & 1.00 & \\
\hline 14. Inward FDI $(\mathrm{t})$ & 12.61 & 31.71 & 0.00 & 100.00 & 0.01 & 0.02 & 0.05 & 0.06 & 0.33 & 0.34 & 0.34 & 0.42 & 0.42 & 0.41 & 0.18 & 0.10 & 0.46 & 1.00 \\
\hline 15. Import $_{(\mathrm{t})}$ & 0.45 & 0.50 & 0.00 & 1.00 & 0.02 & 0.03 & 0.03 & 0.04 & 0.51 & 0.49 & 0.49 & 0.54 & 0.52 & 0.52 & 0.18 & 0.14 & 0.50 & 0.37 \\
\hline
\end{tabular}


Table 4. Descriptive statistics and correlations (split by RDI ${ }^{\text {Spain }}$ )

\begin{tabular}{|c|c|c|c|c|c|c|c|c|c|c|c|c|c|c|c|c|c|c|}
\hline Variable & Mean & S.D. & Min & Max & 1 & 2 & 3 & 4 & 5 & 6 & 7 & 8 & 9 & 10 & 11 & 12 & 13 & 14 \\
\hline \multicolumn{19}{|l|}{ Leaders $(N=2764)$ : } \\
\hline 1. Patent applications $(\mathrm{t})$ & 0.33 & 1.42 & 0.00 & 19.00 & 1.00 & & & & & & & & & & & & & \\
\hline 2. Patent applications $(\mathrm{t}-1)$ & 0.42 & 2.58 & 0.00 & 92.00 & 0.39 & 1.00 & & & & & & & & & & & & \\
\hline 3. Patent applications $(\mathrm{t}-2)$ & 0.42 & 2.51 & 0.00 & 92.00 & 0.36 & 0.32 & 1.00 & & & & & & & & & & & \\
\hline 4. Patent applications $(\mathrm{t}-3)$ & 0.39 & 2.35 & 0.00 & 92.00 & 0.31 & 0.20 & 0.24 & 1.00 & & & & & & & & & & \\
\hline 5. Export status $_{(\mathrm{t}-1)}$ & 0.70 & 0.46 & 0.00 & 1.00 & 0.08 & 0.07 & 0.07 & 0.08 & 1.00 & & & & & & & & & \\
\hline 6. Export status $(\mathrm{t}-2)$ & 0.69 & 0.46 & 0.00 & 1.00 & 0.09 & 0.07 & 0.07 & 0.08 & 0.88 & 1.00 & & & & & & & & \\
\hline 7. Export status $(\mathrm{t}-3)$ & 0.68 & 0.47 & 0.00 & 1.00 & 0.08 & 0.05 & 0.05 & 0.08 & 0.81 & 0.86 & 1.00 & & & & & & & \\
\hline 8. Export volume $(\mathrm{t}-1)$ & 9.23 & 6.33 & 0.00 & 19.74 & 0.09 & 0.07 & 0.07 & 0.09 & 0.95 & 0.87 & 0.82 & 1.00 & & & & & & \\
\hline 9. Export volume $(\mathrm{t}-2)$ & 8.97 & 6.32 & 0.00 & 19.74 & 0.09 & 0.06 & 0.07 & 0.09 & 0.86 & 0.95 & 0.86 & 0.93 & 1.00 & & & & & \\
\hline 10. Export volume $(\mathrm{t}-3)$ & 8.74 & 6.32 & 0.00 & 19.74 & 0.09 & 0.06 & 0.06 & 0.08 & 0.80 & 0.84 & 0.96 & 0.88 & 0.92 & 1.00 & & & & \\
\hline 11. $\mathrm{R} \& \mathrm{D}$ intensity $(\mathrm{t})$ & 1.43 & 2.71 & 0.00 & 27.20 & 0.12 & 0.09 & 0.08 & 0.10 & 0.16 & 0.15 & 0.14 & 0.16 & 0.15 & 0.14 & 1.00 & & & \\
\hline 12. Advertising intensity $(\mathrm{t})$ & 1.96 & 3.70 & 0.00 & 44.90 & 0.09 & 0.04 & 0.05 & 0.04 & 0.18 & 0.18 & 0.18 & 0.16 & 0.16 & 0.15 & 0.09 & 1.00 & & \\
\hline 13. Size $_{(t)}$ & 4.88 & 1.58 & 0.00 & 10.02 & 0.13 & 0.08 & 0.08 & 0.09 & 0.54 & 0.55 & 0.54 & 0.67 & 0.67 & 0.66 & 0.17 & 0.18 & 1.00 & \\
\hline 14. Inward FDI $(\mathrm{t})$ & 24.79 & 40.76 & 0.00 & 100.00 & -0.02 & -0.01 & 0.01 & -0.01 & 0.32 & 0.32 & 0.31 & 0.39 & 0.39 & 0.37 & 0.03 & 0.09 & 0.42 & 1.00 \\
\hline 15. $\operatorname{Import}_{(\mathrm{t})}$ & 0.74 & 0.44 & 0.00 & 1.00 & 0.12 & 0.08 & 0.08 & 0.08 & 0.59 & 0.57 & 0.57 & 0.61 & 0.60 & 0.59 & 0.19 & 0.17 & 0.59 & 0.32 \\
\hline \multicolumn{19}{|l|}{ Laggards $(N=3680)$ : } \\
\hline 1. Patent applications $(\mathrm{t})$ & 0.05 & 0.63 & 0.00 & 24.00 & 1.00 & & & & & & & & & & & & & \\
\hline 2. Patent applications $(\mathrm{t}-1)$ & 0.07 & 0.73 & 0.00 & 24.00 & 0.59 & 1.00 & & & & & & & & & & & & \\
\hline 3. Patent applications $(\mathrm{t}-2)$ & 0.08 & 0.90 & 0.00 & 36.00 & 0.46 & 0.57 & 1.00 & & & & & & & & & & & \\
\hline 4. Patent applications $(\mathrm{t}-3)$ & 0.13 & 1.39 & 0.00 & 43.00 & 0.26 & 0.37 & 0.61 & 1.00 & & & & & & & & & & \\
\hline 5. Export status $(\mathrm{t}-1)$ & 0.44 & 0.50 & 0.00 & 1.00 & 0.03 & 0.04 & 0.05 & 0.06 & 1.00 & & & & & & & & & \\
\hline 6. Export status $(\mathrm{t}-2)$ & 0.41 & 0.49 & 0.00 & 1.00 & 0.03 & 0.04 & 0.05 & 0.06 & 0.84 & 1.00 & & & & & & & & \\
\hline 7. Export status $(\mathrm{t}-3)$ & 0.39 & 0.49 & 0.00 & 1.00 & 0.06 & 0.05 & 0.06 & 0.07 & 0.77 & 0.84 & 1.00 & & & & & & & \\
\hline 8. Export volume $(\mathrm{t}-1)$ & 5.12 & 6.07 & 0.00 & 19.96 & 0.04 & 0.05 & 0.05 & 0.06 & 0.96 & 0.85 & 0.80 & 1.00 & & & & & & \\
\hline 9. Export volume $(\mathrm{t}-2)$ & 4.81 & 6.00 & 0.00 & 19.89 & 0.04 & 0.04 & 0.06 & 0.06 & 0.83 & 0.96 & 0.85 & 0.91 & 1.00 & & & & & \\
\hline 10. Export volume $(\mathrm{t}-3)$ & 4.54 & 5.93 & 0.00 & 19.75 & 0.06 & 0.06 & 0.06 & 0.07 & 0.77 & 0.83 & 0.96 & 0.86 & 0.91 & 1.00 & & & & \\
\hline 11. $R \& D$ intensity $(t)$ & 0.01 & 0.07 & 0.00 & 0.80 & 0.02 & 0.01 & 0.01 & 0.06 & 0.16 & 0.16 & 0.17 & 0.21 & 0.21 & 0.22 & 1.00 & & & \\
\hline 12. Advertising intensity $(\mathrm{t})$ & 0.95 & 2.37 & 0.00 & 41.00 & 0.03 & 0.05 & 0.03 & 0.02 & 0.16 & 0.17 & 0.17 & 0.17 & 0.17 & 0.17 & 0.05 & 1.00 & & \\
\hline 13. $\operatorname{Size}_{(\mathrm{t})}$ & 3.67 & 1.37 & 0.00 & 9.53 & 0.05 & 0.07 & 0.04 & 0.02 & 0.47 & 0.48 & 0.48 & 0.60 & 0.60 & 0.60 & 0.21 & 0.20 & 1.00 & \\
\hline 14. Inward FDI $(\mathrm{t})$ & 12.75 & 31.75 & 0.00 & 100.00 & 0.01 & 0.02 & 0.05 & 0.06 & 0.33 & 0.33 & 0.34 & 0.42 & 0.42 & 0.41 & 0.18 & 0.09 & 0.47 & 1.00 \\
\hline 15. Import $_{(\mathrm{t})}$ & 0.45 & 0.50 & 0.00 & 1.00 & 0.02 & 0.03 & 0.04 & 0.05 & 0.50 & 0.48 & 0.47 & 0.53 & 0.51 & 0.50 & 0.18 & 0.13 & 0.49 & 0.37 \\
\hline
\end{tabular}


Figure 1. Patents by exporting status (RDI ${ }^{O E C D}$ )

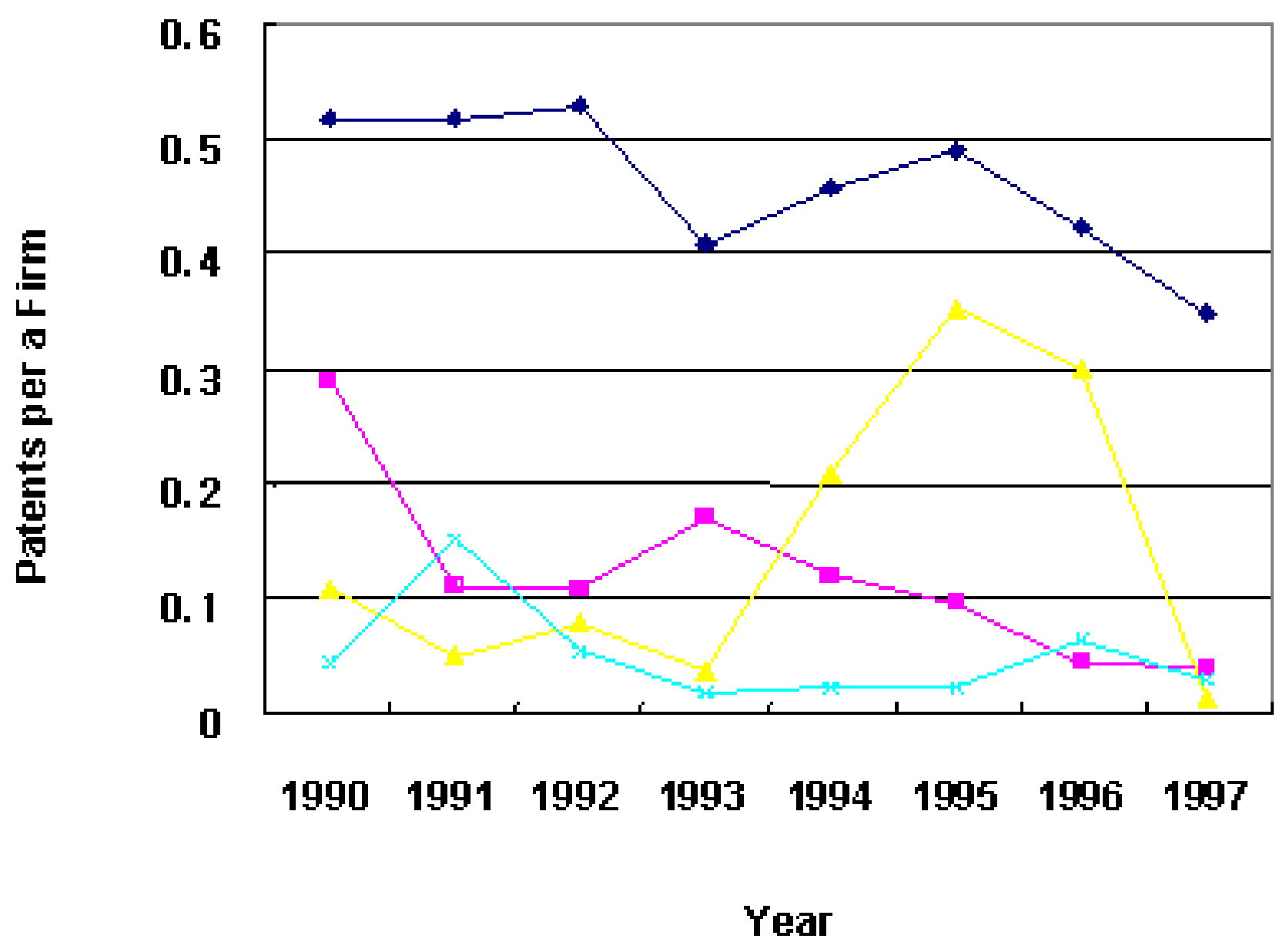

$\rightarrow$ High RDIoeco

Exporter

Low RDIOECD

Exporter

High RDIOEC:

Non-exporter

LOW RDIOECD

Non-exporter

Year 
Figure 2. Patents by exporting status (RDI ${ }^{\text {Spain }}$ )

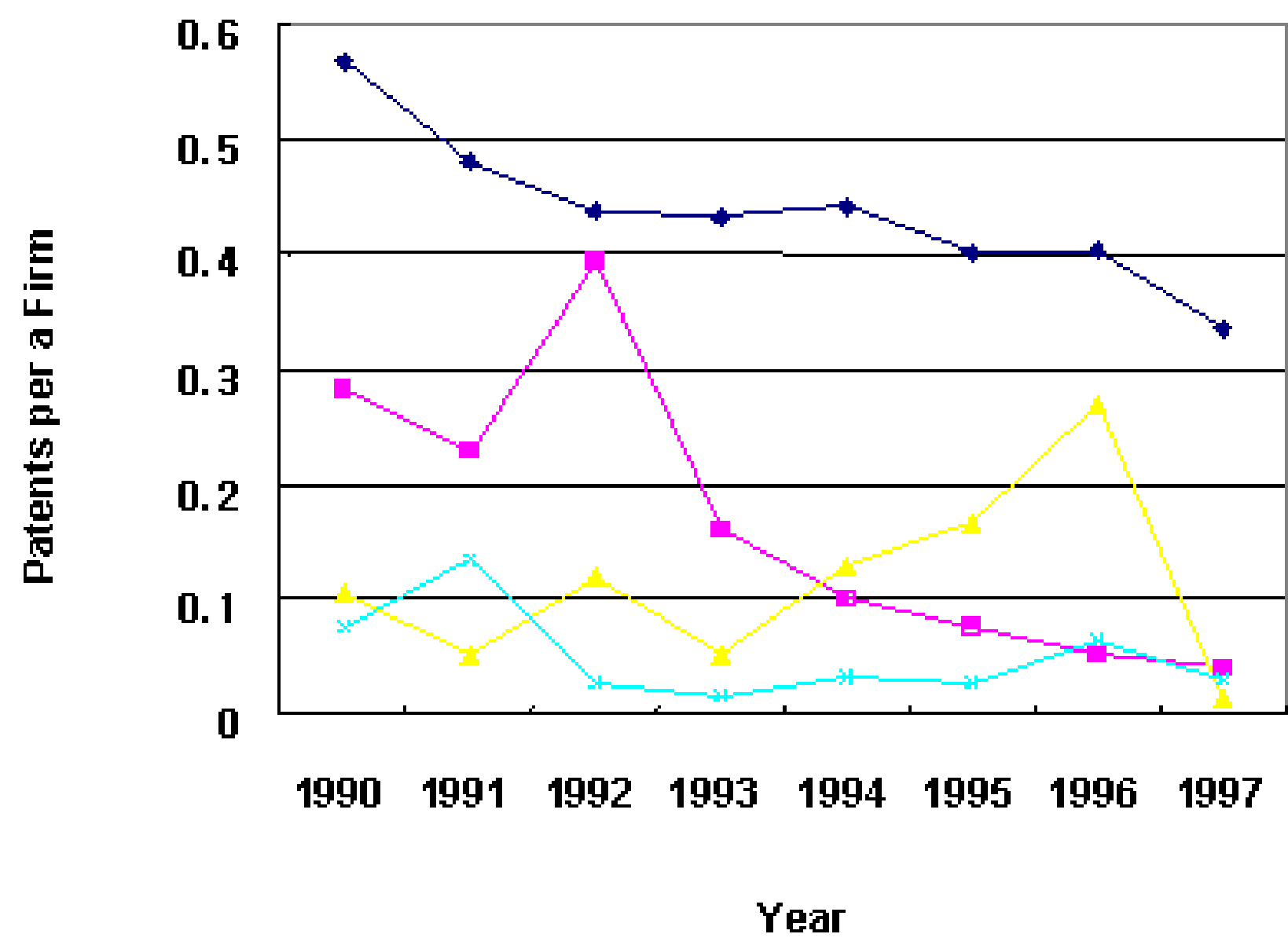

$\rightarrow$ High RDIspaln

Exporter

$\rightarrow$ Low RDI 8 paln

Exporter

High RDI praln

Non-exporter

Low RD| $\left.\right|_{\text {paln }}$

Non-exporter

Year 
Table 5. Negative binomial regressions (Median split by RDI ${ }^{O E C D}$ )

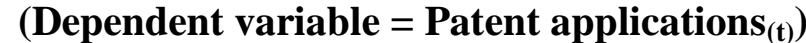

\begin{tabular}{|c|c|c|c|c|c|c|c|c|}
\hline \multirow[t]{2}{*}{ Variable } & \multicolumn{4}{|c|}{ Relative Technological Leaders } & \multicolumn{4}{|c|}{ Relative Technological Laggards } \\
\hline & 1 & 2 & 3 & 4 & 5 & 6 & 7 & 8 \\
\hline Export status $_{(\mathrm{t}-1)}$ & & $\begin{array}{c}0.653^{* * *} \\
(2.64) \\
{[0.07]}\end{array}$ & & & & $\begin{array}{c}0.680^{* * *} \\
(2.39) \\
{[0.02]}\end{array}$ & & \\
\hline Export status $_{(\mathrm{t}-2)}$ & & & $\begin{array}{c}0.631^{* * *} \\
(2.64) \\
{[0.07]}\end{array}$ & & & & $\begin{array}{l}0.613^{* *} \\
(2.17) \\
{[0.02]}\end{array}$ & \\
\hline Export status $_{(\mathrm{t}-3)}$ & & & & $\begin{array}{c}0.719^{* * *} \\
(3.03) \\
{[0.08]}\end{array}$ & & & & $\begin{array}{c}0.533^{* *} \\
(1.92) \\
{[0.02]}\end{array}$ \\
\hline Patent applications $_{(\mathrm{t}-1)}$ & $\begin{array}{c}0.424^{* * *} \\
(6.22) \\
{[0.06]}\end{array}$ & $\begin{array}{c}0.420^{* * *} \\
(6.29) \\
{[0.05]}\end{array}$ & $\begin{array}{c}0.414^{* * *} \\
(6.18) \\
{[0.05]}\end{array}$ & $\begin{array}{c}0.412^{* * *} \\
(6.20) \\
{[0.05]}\end{array}$ & $\begin{array}{c}0.740^{* * * *} \\
(3.20) \\
{[0.02]}\end{array}$ & $\begin{array}{c}0.740^{* * *} \\
(3.32) \\
{[0.02]}\end{array}$ & $\begin{array}{c}0.740^{* * *} \\
(3.29) \\
{[0.02]}\end{array}$ & $\begin{array}{c}0.736^{\text {**** }} \\
(3.26) \\
{[0.02]}\end{array}$ \\
\hline Patent applications $_{(t-2)}$ & $\begin{array}{c}0.228^{* * *} \\
(3.48) \\
{[0.03]}\end{array}$ & $\begin{array}{c}0.235^{* * *} \\
(3.59) \\
{[0.03]}\end{array}$ & $\begin{array}{c}0.235^{* * *} \\
(3.60) \\
{[0.03]}\end{array}$ & $\begin{array}{c}0.237^{* * *} \\
(3.65) \\
{[0.03]}\end{array}$ & $\begin{array}{c}0.347^{* *} \\
(1.66) \\
{[0.01]}\end{array}$ & $\begin{array}{l}0.327^{*} \\
(1.56) \\
{[0.01]}\end{array}$ & $\begin{array}{l}0.317^{*} \\
(1.54) \\
{[0.01]}\end{array}$ & $\begin{array}{l}0.321^{*} \\
(1.55) \\
{[0.01]}\end{array}$ \\
\hline Patent applications $_{(t-3)}$ & $\begin{array}{c}0.147^{* * *} \\
(2.45) \\
{[0.02]}\end{array}$ & $\begin{array}{c}0.131^{* *} \\
(2.22) \\
{[0.02]}\end{array}$ & $\begin{array}{c}0.131^{* *} \\
(2.22) \\
{[0.02]}\end{array}$ & $\begin{array}{l}0.126^{* *} \\
(2.15) \\
{[0.02]}\end{array}$ & $\begin{array}{l}-0.017 \\
(-0.12) \\
{[0.00]}\end{array}$ & $\begin{array}{c}-0.032 \\
(-0.21) \\
{[0.00]}\end{array}$ & $\begin{array}{l}-0.020 \\
(-0.14) \\
{[0.00]}\end{array}$ & $\begin{array}{l}-0.020 \\
(-0.14) \\
{[0.00]}\end{array}$ \\
\hline$R \& D$ intensity $y_{(t)}$ & $\begin{array}{l}0.000 \\
(0.00) \\
{[0.00]}\end{array}$ & $\begin{array}{l}0.003 \\
(0.13) \\
{[0.00]}\end{array}$ & $\begin{array}{l}0.004 \\
(0.13) \\
{[0.00]}\end{array}$ & $\begin{array}{l}0.004 \\
(0.14) \\
{[0.00]}\end{array}$ & $\begin{array}{l}0.773 \\
(0.47) \\
{[0.02]}\end{array}$ & $\begin{array}{l}0.496 \\
(0.30) \\
{[0.01]}\end{array}$ & $\begin{array}{l}0.503 \\
(0.31) \\
{[0.01]}\end{array}$ & $\begin{array}{l}0.585 \\
(0.36) \\
{[0.02]}\end{array}$ \\
\hline Advertising intensity $_{(t)}$ & $\begin{array}{l}0.020 \\
(0.92) \\
{[0.00]}\end{array}$ & $\begin{array}{l}0.012 \\
(0.56) \\
{[0.00]}\end{array}$ & $\begin{array}{l}0.014 \\
(0.62) \\
{[0.00]}\end{array}$ & $\begin{array}{l}0.013 \\
(0.60) \\
{[0.00]}\end{array}$ & $\begin{array}{l}0.019 \\
(0.34) \\
{[0.00]}\end{array}$ & $\begin{array}{l}0.007 \\
(0.13) \\
{[0.00]}\end{array}$ & $\begin{array}{l}0.010 \\
(0.17) \\
{[0.00]}\end{array}$ & $\begin{array}{l}0.012 \\
(0.22) \\
{[0.00]}\end{array}$ \\
\hline $\operatorname{Size}_{(t)}$ & $\begin{array}{c}0.207^{* * *} \\
(3.33) \\
{[0.03]}\end{array}$ & $\begin{array}{c}0.184^{* * *} \\
(2.94) \\
{[0.02]}\end{array}$ & $\begin{array}{c}0.185^{* * *} \\
(2.95) \\
{[0.02]}\end{array}$ & $\begin{array}{c}0.182^{* * *} \\
(2.91) \\
{[0.02]}\end{array}$ & $\begin{array}{l}0.154^{*} \\
(1.44) \\
{[0.00]}\end{array}$ & $\begin{array}{l}0.114 \\
(1.06) \\
{[0.00]}\end{array}$ & $\begin{array}{l}0.109 \\
(1.02) \\
{[0.00]}\end{array}$ & $\begin{array}{l}0.116 \\
(1.07) \\
{[0.00]}\end{array}$ \\
\hline Inward FDI $_{(t)}$ & $\begin{array}{c}-0.003^{* *} \\
(-1.68) \\
{[0.00]}\end{array}$ & $\begin{array}{c}-0.004^{* *} \\
(-1.93) \\
{[0.00]}\end{array}$ & $\begin{array}{c}-0.004^{* *} \\
(-1.94) \\
{[0.00]}\end{array}$ & $\begin{array}{c}-0.004^{* *} \\
(-1.96) \\
{[0.00]}\end{array}$ & $\begin{array}{c}-0.006^{*} \\
(-1.39) \\
{[0.00]}\end{array}$ & $\begin{array}{c}-0.007^{* *} \\
(-1.66) \\
{[0.00]}\end{array}$ & $\begin{array}{c}-0.007^{* *} \\
(-1.67) \\
{[0.00]}\end{array}$ & $\begin{array}{c}-0.007^{*} \\
(-1.63) \\
{[0.00]}\end{array}$ \\
\hline $\operatorname{Import}_{(t)}$ & $\begin{array}{c}0.846^{* * * *} \\
(3.16) \\
{[0.09]}\end{array}$ & $\begin{array}{c}0.639^{* *} \\
(2.26) \\
{[0.07]}\end{array}$ & $\begin{array}{c}0.661^{* * *} \\
(2.37) \\
{[0.07]}\end{array}$ & $\begin{array}{c}0.624^{* *} \\
(2.22) \\
{[0.07]}\end{array}$ & $\begin{array}{l}0.217 \\
(0.78) \\
{[0.01]}\end{array}$ & $\begin{array}{l}0.010 \\
(0.03) \\
{[0.00]}\end{array}$ & $\begin{array}{l}0.061 \\
(0.21) \\
{[0.00]}\end{array}$ & $\begin{array}{l}0.098 \\
(0.34) \\
{[0.00]}\end{array}$ \\
\hline Constant $_{(\mathrm{t})}$ & $\begin{array}{l}-4.383^{* * * *} \\
(-12.43)\end{array}$ & $\begin{array}{c}-4.589^{* * * *} \\
(-12.39)\end{array}$ & $\begin{array}{c}-4.565^{* * *} \\
(-12.44)\end{array}$ & $\begin{array}{c}-4.563^{* * *} \\
(-12.47)\end{array}$ & $\begin{array}{c}-4.420^{* * *} \\
(-9.14)\end{array}$ & $\begin{array}{c}-4.530^{* * * *} \\
(-9.30)\end{array}$ & $\begin{array}{c}-4.440^{* * * *} \\
(-9.19)\end{array}$ & $\begin{array}{c}-4.447^{* * *} \\
(-9.19)\end{array}$ \\
\hline Year effects & Included & Included & Included & Included & Included & Included & Included & Included \\
\hline $\mathrm{N}$ & 2474 & 2474 & 2474 & 2474 & 3970 & 3970 & 3970 & 3970 \\
\hline $\begin{array}{c}\text { Log likelihood } \\
-2 \Delta \mathrm{L}\end{array}$ & -1185.433 & $\begin{array}{c}-1181.944 \\
6.978^{* * * *}\end{array}$ & $\begin{array}{c}-1181.931 \\
7.004^{* * *}\end{array}$ & $\begin{array}{c}-1180.826 \\
9.214^{* * *}\end{array}$ & -528.412 & $\begin{array}{c}-525.543 \\
5.738^{* *}\end{array}$ & $\begin{array}{c}-526.059 \\
4.706^{* * *}\end{array}$ & $\begin{array}{c}-526.568 \\
3.688^{*}\end{array}$ \\
\hline
\end{tabular}

$: \mathrm{p}<.10 ;{ }^{* *}: \mathrm{p}<.05 ;{ }^{* * *}: \mathrm{p}<.01$ (One-tailed tests)

t-statistics appear in (parentheses); marginal effects in [brackets] 
Table 6. Negative binomial regressions (Median split by RDI ${ }^{O E C D}$ )

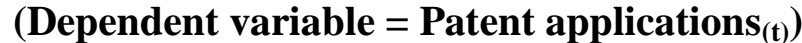

\begin{tabular}{|c|c|c|c|c|c|c|}
\hline \multirow[t]{2}{*}{ Variable } & \multicolumn{3}{|c|}{ Relative Technological Leaders } & \multicolumn{3}{|c|}{ Relative Technological Laggards } \\
\hline & 1 & 2 & 3 & 4 & 5 & 6 \\
\hline Export volume $_{(t-1)}$ & $\begin{array}{c}0.053^{* * *} \\
(2.85) \\
{[0.01]}\end{array}$ & & & $\begin{array}{c}0.055^{* *} \\
(2.19) \\
{[0.00]}\end{array}$ & & \\
\hline Export volume $_{(\mathrm{t}-2)}$ & & $\begin{array}{c}0.052^{* * *} \\
(2.84) \\
{[0.01]}\end{array}$ & & & $\begin{array}{l}0.036^{*} \\
(1.35) \\
{[0.00]}\end{array}$ & \\
\hline Export volume $_{(t-3)}$ & & & $\begin{array}{c}0.054^{* * *} \\
(2.96) \\
{[0.01]}\end{array}$ & & & $\begin{array}{l}0.029 \\
(1.12) \\
{[0.00]}\end{array}$ \\
\hline Patent applications $_{(\mathrm{t}-1)}$ & $\begin{array}{c}0.414^{* * *} \\
(6.22) \\
{[0.05]}\end{array}$ & $\begin{array}{c}0.406^{* * *} \\
(6.10) \\
{[0.05]}\end{array}$ & $\begin{array}{c}0.406^{* * *} \\
(6.12) \\
{[0.05]}\end{array}$ & $\begin{array}{c}0.756^{* * *} \\
(3.35) \\
{[0.02]}\end{array}$ & $\begin{array}{c}0.746^{* * *} \\
(3.26) \\
{[0.02]}\end{array}$ & $\begin{array}{c}0.743^{\text {**** }} \\
(3.24) \\
{[0.02]}\end{array}$ \\
\hline Patent applications $s_{(t-2)}$ & $\begin{array}{c}0.241^{* * *} \\
(3.65) \\
{[0.03]}\end{array}$ & $\begin{array}{c}0.240^{* * *} \\
(3.67) \\
{[0.03]}\end{array}$ & $\begin{array}{c}0.241^{* * * *} \\
(3.69) \\
{[0.03]}\end{array}$ & $\begin{array}{l}0.321^{*} \\
(1.55) \\
{[0.01]}\end{array}$ & $\begin{array}{l}0.324^{*} \\
(1.56) \\
{[0.01]}\end{array}$ & $\begin{array}{l}0.327^{*} \\
(1.57) \\
{[0.01]}\end{array}$ \\
\hline Patent applications $_{(t-3)}$ & $\begin{array}{c}0.135^{* *} \\
(2.30) \\
{[0.02]}\end{array}$ & $\begin{array}{l}0.133^{*} \\
(2.27) \\
{[0.02]}\end{array}$ & $\begin{array}{l}0.129^{*} \\
(2.21) \\
{[0.02]}\end{array}$ & $\begin{array}{c}-0.026 \\
(-0.18) \\
{[0.00]}\end{array}$ & $\begin{array}{c}-0.021 \\
(-0.14) \\
{[0.00]}\end{array}$ & $\begin{array}{l}-0.021 \\
(-0.15) \\
{[0.00]}\end{array}$ \\
\hline$R \& D$ intensity $(t)$ & $\begin{array}{l}0.005 \\
(0.18) \\
{[0.00]}\end{array}$ & $\begin{array}{l}0.005 \\
(0.19) \\
{[0.00]}\end{array}$ & $\begin{array}{l}0.006 \\
(0.22) \\
{[0.00]}\end{array}$ & $\begin{array}{l}0.316 \\
(0.19) \\
{[0.01]}\end{array}$ & $\begin{array}{l}0.431 \\
(0.26) \\
{[0.01]}\end{array}$ & $\begin{array}{l}0.546 \\
(0.33) \\
{[0.02]}\end{array}$ \\
\hline 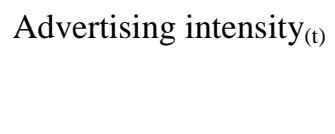 & $\begin{array}{l}0.016 \\
(0.74) \\
{[0.00]}\end{array}$ & $\begin{array}{l}0.018 \\
(0.81) \\
{[0.00]}\end{array}$ & $\begin{array}{l}0.019 \\
(0.85) \\
{[0.00]}\end{array}$ & $\begin{array}{l}0.010 \\
(0.18) \\
{[0.00]}\end{array}$ & $\begin{array}{l}0.013 \\
(0.24) \\
{[0.00]}\end{array}$ & $\begin{array}{l}0.015 \\
(0.26) \\
{[0.00]}\end{array}$ \\
\hline $\operatorname{Size}_{(t)}$ & $\begin{array}{c}0.138^{* *} \\
(2.09) \\
{[0.02]}\end{array}$ & $\begin{array}{c}0.140^{* *} \\
(2.12) \\
{[0.02]}\end{array}$ & $\begin{array}{c}0.137^{* *} \\
(2.07) \\
{[0.02]}\end{array}$ & $\begin{array}{l}0.078 \\
(0.70) \\
{[0.00]}\end{array}$ & $\begin{array}{c}0.111 \\
(1.00) \\
{[0.00]}\end{array}$ & $\begin{array}{l}0.120 \\
(1.09) \\
{[0.00]}\end{array}$ \\
\hline Inward $\operatorname{FDI}_{(t)}$ & $\begin{array}{c}-0.004^{* *} \\
(-2.13) \\
{[0.00]}\end{array}$ & $\begin{array}{c}-0.004^{* *} \\
(-2.12) \\
{[0.00]}\end{array}$ & $\begin{array}{c}-0.004^{* *} \\
(-2.11) \\
{[0.00]}\end{array}$ & $\begin{array}{c}-0.008^{* *} \\
(-1.78) \\
{[0.00]}\end{array}$ & $\begin{array}{c}-0.008^{* *} \\
(-1.65) \\
{[0.00]}\end{array}$ & $\begin{array}{c}-0.007^{*} \\
(-1.58) \\
{[0.00]}\end{array}$ \\
\hline $\operatorname{Import}_{(\mathrm{t})}$ & $\begin{array}{c}0.654^{* * *} \\
(2.34) \\
{[0.07]}\end{array}$ & $\begin{array}{c}0.671^{* * *} \\
(2.42) \\
{[0.07]}\end{array}$ & $\begin{array}{c}0.654^{* * *} \\
(2.36) \\
{[0.07]}\end{array}$ & $\begin{array}{l}0.054 \\
(0.18) \\
{[0.00]}\end{array}$ & $\begin{array}{l}0.114 \\
(0.39) \\
{[0.00]}\end{array}$ & $\begin{array}{l}0.140 \\
(0.49) \\
{[0.00]}\end{array}$ \\
\hline Constant $_{(t)}$ & $\begin{array}{c}-4.376^{* * *} \\
(-12.28)\end{array}$ & $\begin{array}{c}-4.360^{* * *} \\
(-12.27)\end{array}$ & $\begin{array}{c}-4.337^{* * *} \\
(-12.21)\end{array}$ & $\begin{array}{c}-4.391^{* * *} \\
(-9.08)\end{array}$ & $\begin{array}{c}-4.388^{* * *} \\
(-9.06)\end{array}$ & $\begin{array}{c}-4.403^{* * *} \\
(-9.10)\end{array}$ \\
\hline Year effects & Included & Included & Included & Included & Included & Included \\
\hline $\mathrm{N}$ & 2474 & 2474 & 2474 & 3970 & 3970 & 3970 \\
\hline Log likelihood & -1181.420 & -1181.401 & -1181.077 & -525.994 & -527.494 & -527.781 \\
\hline$-2 \Delta \mathrm{L}$ & $8.026^{* * *}$ & $8.064^{* * *}$ & $8.712^{* * * *}$ & $4.836^{* *}$ & 1.836 & 1.262 \\
\hline
\end{tabular}

$: \mathrm{p}<.10 ;{ }^{* *}: \mathrm{p}<.05 ;{ }^{* * * *}: \mathrm{p}<.01$ (One-tailed tests)

$\mathrm{t}$-statistics appear in (parentheses); marginal effects in [brackets] 
Table 7. Negative binomial regressions (Median split by RDI $^{\text {Spain }}$ )

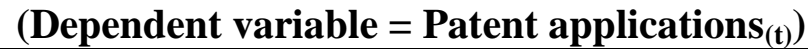

\begin{tabular}{|c|c|c|c|c|c|c|c|c|}
\hline \multirow[t]{2}{*}{ Variable } & \multicolumn{4}{|c|}{ Relative Technological Leaders } & \multicolumn{4}{|c|}{ Relative Technological Laggards } \\
\hline & 1 & 2 & 3 & 4 & 5 & 6 & 7 & 8 \\
\hline Export status $_{(\mathrm{t}-1)}$ & & $\begin{array}{c}0.881^{\text {*** }} \\
(3.64) \\
{[0.08]}\end{array}$ & & & & $\begin{array}{c}0.539^{* *} \\
(1.79) \\
{[0.01]}\end{array}$ & & \\
\hline Export status $_{(\mathrm{t}-2)}$ & & & $\begin{array}{c}0.742^{* * *} \\
(3.20) \\
{[0.07]}\end{array}$ & & & & $\begin{array}{c}0.589^{* *} \\
(1.97) \\
{[0.02]}\end{array}$ & \\
\hline Export status $_{(\mathrm{t}-3)}$ & & & & $\begin{array}{c}0.718^{* * *} \\
(3.16) \\
{[0.07]}\end{array}$ & & & & $\begin{array}{c}0.662^{* *} \\
(2.22) \\
{[0.02]}\end{array}$ \\
\hline Patent applications $_{(\mathrm{t}-1)}$ & $\begin{array}{c}0.428^{* * *} \\
(6.36) \\
{[0.05]}\end{array}$ & $\begin{array}{c}0.425^{\text {*** }} \\
(6.47) \\
{[0.05]}\end{array}$ & $\begin{array}{c}0.416^{* * *} \\
(6.31) \\
{[0.05]}\end{array}$ & $\begin{array}{c}0.415^{* * *} \\
(6.33) \\
{[0.05]}\end{array}$ & $\begin{array}{c}0.761^{* * *} \\
(3.17) \\
{[0.02]}\end{array}$ & $\begin{array}{c}0.759^{* * *} \\
(3.26) \\
{[0.02]}\end{array}$ & $\begin{array}{c}0.766^{* * *} \\
(3.27) \\
{[0.02]}\end{array}$ & $\begin{array}{c}0.765^{\text {*** }} \\
(3.29) \\
{[0.02]}\end{array}$ \\
\hline Patent applications $_{(\mathrm{t}-2)}$ & $\begin{array}{c}0.229^{* * *} \\
(3.65) \\
{[0.03]}\end{array}$ & $\begin{array}{c}0.234^{* * *} \\
(3.75) \\
{[0.03]}\end{array}$ & $\begin{array}{c}0.232^{* * *} \\
(3.74) \\
{[0.03]}\end{array}$ & $\begin{array}{c}0.232^{* * *} \\
(3.75) \\
{[0.03]}\end{array}$ & $\begin{array}{l}0.440^{*} \\
(1.33) \\
{[0.01]}\end{array}$ & $\begin{array}{l}0.439^{*} \\
(1.33) \\
{[0.01]}\end{array}$ & $\begin{array}{l}0.434^{*} \\
(1.31) \\
{[0.01]}\end{array}$ & $\begin{array}{l}0.443^{*} \\
(1.33) \\
{[0.01]}\end{array}$ \\
\hline Patent applications $_{(\mathrm{t}-3)}$ & $\begin{array}{c}0.154^{* * *} \\
(2.57) \\
{[0.02]}\end{array}$ & $\begin{array}{c}0.133^{* *} \\
(2.27) \\
{[0.01]}\end{array}$ & $\begin{array}{c}0.137^{* * *} \\
(2.33) \\
{[0.01]}\end{array}$ & $\begin{array}{c}0.134^{* *} \\
(2.30) \\
{[0.01]}\end{array}$ & $\begin{array}{c}-0.106 \\
(-0.40) \\
{[0.00]}\end{array}$ & $\begin{array}{c}-0.126 \\
(-0.47) \\
{[0.00]}\end{array}$ & $\begin{array}{c}-0.132 \\
(-0.49) \\
{[0.00]}\end{array}$ & $\begin{array}{c}-0.139 \\
(-0.52) \\
{[0.00]}\end{array}$ \\
\hline R\&D intensity $(t)$ & $\begin{array}{l}0.010 \\
(0.35) \\
{[0.00]}\end{array}$ & $\begin{array}{l}0.015 \\
(0.52) \\
{[0.00]}\end{array}$ & $\begin{array}{l}0.013 \\
(0.48) \\
{[0.00]}\end{array}$ & $\begin{array}{l}0.012 \\
(0.45) \\
{[0.00]}\end{array}$ & $\begin{array}{l}0.600 \\
(0.32) \\
{[0.02]}\end{array}$ & $\begin{array}{l}0.398 \\
(0.21) \\
{[0.01]}\end{array}$ & $\begin{array}{l}0.364 \\
(0.20) \\
{[0.01]}\end{array}$ & $\begin{array}{l}0.263 \\
(0.14) \\
{[0.01]}\end{array}$ \\
\hline Advertising intensity $_{(t)}$ & $\begin{array}{l}0.024 \\
(1.11) \\
{[0.00]}\end{array}$ & $\begin{array}{l}0.014 \\
(0.63) \\
{[0.00]}\end{array}$ & $\begin{array}{l}0.017 \\
(0.76) \\
{[0.00]}\end{array}$ & $\begin{array}{l}0.017 \\
(0.77) \\
{[0.00]}\end{array}$ & $\begin{array}{l}0.020 \\
(0.34) \\
{[0.00]}\end{array}$ & $\begin{array}{l}0.009 \\
(0.15) \\
{[0.00]}\end{array}$ & $\begin{array}{l}0.009 \\
(0.14) \\
{[0.00]}\end{array}$ & $\begin{array}{l}0.013 \\
(0.21) \\
{[0.00]}\end{array}$ \\
\hline $\operatorname{Size}_{(\mathrm{t})}$ & $\begin{array}{c}0.218^{* * *} \\
(3.59) \\
{[0.03]}\end{array}$ & $\begin{array}{c}0.189^{* * *} \\
(3.10) \\
{[0.02]}\end{array}$ & $\begin{array}{c}0.192^{* * *} \\
(3.13) \\
{[0.02]}\end{array}$ & $\begin{array}{c}0.193^{\text {*** }} \\
(3.17) \\
{[0.02]}\end{array}$ & $\begin{array}{l}0.177^{*} \\
(1.57) \\
{[0.00]}\end{array}$ & $\begin{array}{l}0.144 \\
(1.27) \\
{[0.00]}\end{array}$ & $\begin{array}{l}0.134 \\
(1.18) \\
{[0.00]}\end{array}$ & $\begin{array}{l}0.127 \\
(1.11) \\
{[0.00]}\end{array}$ \\
\hline Inward $\mathrm{FDI}_{(\mathrm{t})}$ & $\begin{array}{c}-0.003^{*} \\
(-1.44) \\
{[0.00]}\end{array}$ & $\begin{array}{c}-0.004^{* *} \\
(-1.82) \\
{[0.00]}\end{array}$ & $\begin{array}{c}-0.004^{* *} \\
(-1.78) \\
{[0.00]}\end{array}$ & $\begin{array}{c}-0.003^{* *} \\
(-1.74) \\
{[0.00]}\end{array}$ & $\begin{array}{c}-0.009^{* *} \\
(-1.82) \\
{[0.00]}\end{array}$ & $\begin{array}{c}-0.010^{* *} \\
(-2.01) \\
{[0.00]}\end{array}$ & $\begin{array}{c}-0.010^{* *} \\
(-2.04) \\
{[0.00]}\end{array}$ & $\begin{array}{c}-0.011^{* *} \\
(-2.09) \\
{[0.00]}\end{array}$ \\
\hline $\operatorname{Import}_{(\mathrm{t})}$ & $\begin{array}{c}1.062^{* * *} \\
(4.04) \\
{[0.10]}\end{array}$ & $\begin{array}{c}0.800^{* * *} \\
(2.89) \\
{[0.07]}\end{array}$ & $\begin{array}{c}0.850^{* * *} \\
(3.10) \\
{[0.08]}\end{array}$ & $\begin{array}{c}0.838^{* * *} \\
(3.05) \\
{[0.08]}\end{array}$ & $\begin{array}{l}0.109 \\
(0.37) \\
{[0.00]}\end{array}$ & $\begin{array}{c}-0.063 \\
(-0.21) \\
{[0.00]}\end{array}$ & $\begin{array}{c}-0.049 \\
(-0.16) \\
{[0.00]}\end{array}$ & $\begin{array}{l}-0.049 \\
(-0.16) \\
{[0.00]}\end{array}$ \\
\hline Constant $_{(\mathrm{t})}$ & $\begin{array}{l}-4.593^{* * *} \\
(-12.85)\end{array}$ & $\begin{array}{l}-4.911^{* * *} \\
(-12.85)\end{array}$ & $\begin{array}{l}-4.814^{* * *} \\
(-12.91)\end{array}$ & $\begin{array}{l}-4.773^{* * *} \\
(-12.91)\end{array}$ & $\begin{array}{c}-4.568^{* * *} \\
(-9.12)\end{array}$ & $\begin{array}{c}-4.644^{* * *} \\
(-9.22)\end{array}$ & $\begin{array}{c}-4.582^{* * *} \\
(-9.15)\end{array}$ & $\begin{array}{c}-4.588^{* * *} \\
(-9.15)\end{array}$ \\
\hline Year effects & Included & Included & Included & Included & Included & Included & Included & Included \\
\hline $\mathrm{N}$ & 2764 & 2764 & 2764 & 2764 & 3680 & 3680 & 3680 & 3680 \\
\hline $\begin{array}{l}\text { Log likelihood } \\
-2 \Delta \mathrm{L}\end{array}$ & -1235.023 & $\begin{array}{l}-1228.307 \\
13.432^{* * *}\end{array}$ & $\begin{array}{l}-1229.854 \\
10.338^{* * *}\end{array}$ & $\begin{array}{c}-1230.026 \\
9.994^{* * *}\end{array}$ & -479.119 & $\begin{array}{c}-477.513 \\
3.212^{*}\end{array}$ & $\begin{array}{c}-477.174 \\
3.890^{* *}\end{array}$ & $\begin{array}{c}-476.631 \\
4.976^{* *}\end{array}$ \\
\hline
\end{tabular}

$: p<.10 ;{ }^{* * *}: p<.05 ;{ }^{* * * *}: p<.01$ (One-tailed tests)

$\mathrm{t}$-statistics appear in (parentheses); marginal effects in [brackets] 
Table 8. Negative binomial regressions (Median split by RDI $^{\text {Spain }}$ ) $\left(\right.$ Dependent variable $=$ Patent applications $\left._{(t)}\right)$

\begin{tabular}{|c|c|c|c|c|c|c|}
\hline \multirow[t]{2}{*}{ Variable } & \multicolumn{3}{|c|}{ Relative Technological Leaders } & \multicolumn{3}{|c|}{ Relative Technological Laggards } \\
\hline & 1 & 2 & 3 & 4 & 5 & 6 \\
\hline Export volume $_{(t-1)}$ & $\begin{array}{c}0.064^{* * *} \\
(3.54) \\
{[0.01]}\end{array}$ & & & $\begin{array}{c}0.050^{* *} \\
(1.86) \\
{[0.00]}\end{array}$ & & \\
\hline Export volume $_{(t-2)}$ & & $\begin{array}{c}0.059^{\text {*** }} \\
(3.34) \\
{[0.01]}\end{array}$ & & & $\begin{array}{l}0.037^{*} \\
(1.33) \\
{[0.00]}\end{array}$ & \\
\hline Export volume $_{(t-3)}$ & & & $\begin{array}{c}0.054^{* * *} \\
(3.04) \\
{[0.01]}\end{array}$ & & & $\begin{array}{l}0.045^{*} \\
(1.64) \\
{[0.00]}\end{array}$ \\
\hline Patent applications $_{(\mathrm{t}-1)}$ & $\begin{array}{c}0.417^{* * *} \\
(6.36) \\
{[0.05]}\end{array}$ & $\begin{array}{c}0.408^{* * *} \\
(6.21) \\
{[0.04]}\end{array}$ & $\begin{array}{c}0.410^{* * *} \\
(6.24) \\
{[0.05]}\end{array}$ & $\begin{array}{c}0.772^{* * *} \\
(3.31) \\
{[0.02]}\end{array}$ & $\begin{array}{c}0.768^{* * *} \\
(3.24) \\
{[0.02]}\end{array}$ & $\begin{array}{c}0.770^{\text {*** }} \\
(3.27) \\
{[0.02]}\end{array}$ \\
\hline Patent applications $s_{(t-2)}$ & $\begin{array}{c}0.241^{* * *} \\
(3.82) \\
{[0.03]}\end{array}$ & $\begin{array}{c}0.238^{* * *} \\
(3.82) \\
{[0.03]}\end{array}$ & $\begin{array}{c}0.237^{* * *} \\
(3.81) \\
{[0.03]}\end{array}$ & $\begin{array}{l}0.430^{*} \\
(1.29) \\
{[0.01]}\end{array}$ & $\begin{array}{l}0.432^{*} \\
(1.30) \\
{[0.01]}\end{array}$ & $\begin{array}{l}0.434^{*} \\
(1.30) \\
{[0.01]}\end{array}$ \\
\hline Patent applications $_{(t-3)}$ & $\begin{array}{c}0.141^{* * *} \\
(2.41) \\
{[0.02]}\end{array}$ & $\begin{array}{c}0.140^{* * *} \\
(2.38) \\
{[0.02]}\end{array}$ & $\begin{array}{c}0.137^{* * *} \\
(2.35) \\
{[0.02]}\end{array}$ & $\begin{array}{c}-0.134 \\
(-0.49) \\
{[0.00]}\end{array}$ & $\begin{array}{c}-0.128 \\
(-0.47) \\
{[0.00]}\end{array}$ & $\begin{array}{c}-0.137 \\
(-0.50) \\
{[0.00]}\end{array}$ \\
\hline$R \& D$ intensity $y_{(t)}$ & $\begin{array}{l}0.015 \\
(0.54) \\
{[0.00]}\end{array}$ & $\begin{array}{l}0.015 \\
(0.53) \\
{[0.00]}\end{array}$ & $\begin{array}{l}0.014 \\
(0.51) \\
{[0.00]}\end{array}$ & $\begin{array}{l}0.203 \\
(0.11) \\
{[0.01]}\end{array}$ & $\begin{array}{l}0.262 \\
(0.14) \\
{[0.01]}\end{array}$ & $\begin{array}{l}0.167 \\
(0.09) \\
{[0.00]}\end{array}$ \\
\hline Advertising intensity $_{(t)}$ & $\begin{array}{l}0.019 \\
(0.88) \\
{[0.00]}\end{array}$ & $\begin{array}{l}0.021 \\
(0.99) \\
{[0.00]}\end{array}$ & $\begin{array}{l}0.022 \\
(1.02) \\
{[0.00]}\end{array}$ & $\begin{array}{l}0.011 \\
(0.19) \\
{[0.00]}\end{array}$ & $\begin{array}{l}0.013 \\
(0.22) \\
{[0.00]}\end{array}$ & $\begin{array}{l}0.015 \\
(0.24) \\
{[0.00]}\end{array}$ \\
\hline $\operatorname{Size}_{(t)}$ & $\begin{array}{l}0.135^{* *} \\
(2.09) \\
{[0.01]}\end{array}$ & $\begin{array}{c}0.141^{* *} \\
(2.19) \\
{[0.02]}\end{array}$ & $\begin{array}{c}0.149^{* *} \\
(2.31) \\
{[0.02]}\end{array}$ & $\begin{array}{l}0.107 \\
(0.91) \\
{[0.00]}\end{array}$ & $\begin{array}{l}0.131 \\
(1.12) \\
{[0.00]}\end{array}$ & $\begin{array}{l}0.121 \\
(1.03) \\
{[0.00]}\end{array}$ \\
\hline Inward $\operatorname{FDI}_{(t)}$ & $\begin{array}{c}-0.004^{* *} \\
(-2.01) \\
{[0.00]}\end{array}$ & $\begin{array}{c}-0.004^{* *} \\
(-1.98) \\
{[0.00]}\end{array}$ & $\begin{array}{c}-0.004^{* *} \\
(-1.88) \\
{[0.00]}\end{array}$ & $\begin{array}{c}-0.011^{* *} \\
(-2.13) \\
{[0.00]}\end{array}$ & $\begin{array}{c}-0.011^{* *} \\
(-2.05) \\
{[0.00]}\end{array}$ & $\begin{array}{c}-0.011^{\text {** }} \\
(-2.11) \\
{[0.00]}\end{array}$ \\
\hline $\operatorname{Import}_{(\mathrm{t})}$ & $\begin{array}{c}0.841^{* * *} \\
(3.07) \\
{[0.08]}\end{array}$ & $\begin{array}{c}0.868^{\text {*** }} \\
(3.19) \\
{[0.08]}\end{array}$ & $\begin{array}{c}0.874^{* * *} \\
(3.21) \\
{[0.08]}\end{array}$ & $\begin{array}{c}-0.045 \\
(-0.15) \\
{[0.00]}\end{array}$ & $\begin{array}{c}-0.004 \\
(-0.01) \\
{[0.00]}\end{array}$ & $\begin{array}{c}-0.022 \\
(-0.07) \\
{[0.00]}\end{array}$ \\
\hline Constant $_{(t)}$ & $\begin{array}{c}-4.607^{* * *} \\
(-12.69)\end{array}$ & $\begin{array}{c}-4.573^{* * *} \\
(-12.68)\end{array}$ & $\begin{array}{c}-4.547^{* * *} \\
(-12.64)\end{array}$ & $\begin{array}{c}-4.528^{* * *} \\
(-9.04)\end{array}$ & $\begin{array}{c}-4.528^{* * *} \\
(-9.02)\end{array}$ & $\begin{array}{c}-4.527^{* * *} \\
(-9.02)\end{array}$ \\
\hline Year effects & Included & Included & Included & Included & Included & Included \\
\hline $\mathrm{N}$ & 2764 & 2764 & 2764 & 3680 & 3680 & 3680 \\
\hline Log likelihood & -1228.771 & -1229.439 & -1230.408 & -477.380 & -478.233 & -477.762 \\
\hline$-2 \Delta \mathrm{L}$ & $12.504^{* * *}$ & $11.168^{* * *}$ & $9.23^{* * *}$ & $3.478^{*}$ & 1.772 & $2.714^{*}$ \\
\hline
\end{tabular}

$: \mathrm{p}<.10 ;{ }^{* *}: \mathrm{p}<.05 ;{ }^{* * * *}: \mathrm{p}<.01$ (One-tailed tests)

$\mathrm{t}$-statistics appear in (parentheses); marginal effects in [brackets] 
Table 9. Negative binomial regressions (Split by R\&D) (Dependent variable $=$ Patent applications $\left._{(t)}\right)$

\begin{tabular}{|c|c|c|c|c|c|c|c|c|}
\hline \multirow[t]{2}{*}{ Variable } & \multicolumn{4}{|c|}{ Relative Technological Leaders } & \multicolumn{4}{|c|}{ Relative Technological Laggards } \\
\hline & 1 & 2 & 3 & 4 & 5 & 6 & 7 & 8 \\
\hline Export status $_{(\mathrm{t}-1)}$ & & $\begin{array}{c}0.540^{* *} \\
(2.01) \\
{[0.08]}\end{array}$ & & & & $\begin{array}{c}0.608^{* *} \\
(2.16) \\
{[0.02]}\end{array}$ & & \\
\hline Export status $_{(\mathrm{t}-2)}$ & & & $\begin{array}{c}0.520^{* *} \\
(2.01) \\
{[0.08]}\end{array}$ & & & & $\begin{array}{c}0.528^{* *} \\
(1.89) \\
{[0.01]}\end{array}$ & \\
\hline Export status $_{(\mathrm{t}-3)}$ & & & & $\begin{array}{c}0.545^{* *} \\
(2.16) \\
{[0.08]}\end{array}$ & & & & $\begin{array}{c}0.536^{* *} \\
(1.94) \\
{[0.02]}\end{array}$ \\
\hline Patent applications $s_{(t-1)}$ & $\begin{array}{c}0.451^{* * *} \\
(6.55) \\
{[0.08]}\end{array}$ & $\begin{array}{c}0.447^{\text {**** }} \\
(6.59) \\
{[0.08]}\end{array}$ & $\begin{array}{c}0.441^{\text {*** }} \\
(6.50) \\
{[0.08]}\end{array}$ & $\begin{array}{c}0.440^{* * *} \\
(6.51) \\
{[0.08]}\end{array}$ & $\begin{array}{c}0.589^{* * *} \\
(2.95) \\
{[0.02]}\end{array}$ & $\begin{array}{c}0.605^{* * *} \\
(3.11) \\
{[0.02]}\end{array}$ & $\begin{array}{c}0.605^{* * *} \\
(3.06) \\
{[0.02]}\end{array}$ & $\begin{array}{c}0.604^{* * *} \\
(3.06) \\
{[0.02]}\end{array}$ \\
\hline Patent applications $_{(\mathrm{t}-2)}$ & $\begin{array}{c}0.268^{* * *} \\
(4.13) \\
{[0.05]}\end{array}$ & $\begin{array}{c}0.272^{* * *} \\
(4.19) \\
{[0.05]}\end{array}$ & $\begin{array}{c}0.270^{* * *} \\
(4.17) \\
{[0.05]}\end{array}$ & $\begin{array}{c}0.270^{* * *} \\
(4.19) \\
{[0.05]}\end{array}$ & $\begin{array}{l}0.238 \\
(1.25) \\
{[0.01]}\end{array}$ & $\begin{array}{l}0.220 \\
(1.16) \\
{[0.01]}\end{array}$ & $\begin{array}{l}0.218 \\
(1.15) \\
{[0.01]}\end{array}$ & $\begin{array}{l}0.219 \\
(1.15) \\
{[0.01]}\end{array}$ \\
\hline Patent applications $s_{(t-3)}$ & $\begin{array}{c}0.103^{* *} \\
(1.88) \\
{[0.02]}\end{array}$ & $\begin{array}{c}0.095^{* *} \\
(1.76) \\
{[0.02]}\end{array}$ & $\begin{array}{c}0.095^{* *} \\
(1.75) \\
{[0.02]}\end{array}$ & $\begin{array}{c}0.092^{* *} \\
(1.72) \\
{[0.02]}\end{array}$ & $\begin{array}{l}0.044 \\
(0.27) \\
{[0.00]}\end{array}$ & $\begin{array}{l}0.026 \\
(0.17) \\
{[0.00]}\end{array}$ & $\begin{array}{l}0.041 \\
(0.25) \\
{[0.00]}\end{array}$ & $\begin{array}{l}0.039 \\
(0.24) \\
{[0.00]}\end{array}$ \\
\hline Advertising intensity $_{(t)}$ & $\begin{array}{l}0.012 \\
(0.58) \\
{[0.00]}\end{array}$ & $\begin{array}{l}0.008 \\
(0.38) \\
{[0.00]}\end{array}$ & $\begin{array}{l}0.009 \\
(0.42) \\
{[0.00]}\end{array}$ & $\begin{array}{l}0.009 \\
(0.41) \\
{[0.00]}\end{array}$ & $\begin{array}{l}0.024 \\
(0.40) \\
{[0.00]}\end{array}$ & $\begin{array}{l}0.010 \\
(0.16) \\
{[0.00]}\end{array}$ & $\begin{array}{l}0.012 \\
(0.21) \\
{[0.00]}\end{array}$ & $\begin{array}{l}0.016 \\
(0.27) \\
{[0.00]}\end{array}$ \\
\hline $\operatorname{Size}_{(t)}$ & $\begin{array}{c}0.144^{* *} \\
(2.29) \\
{[0.03]}\end{array}$ & $\begin{array}{c}0.131^{* *} \\
(2.08) \\
{[0.02]}\end{array}$ & $\begin{array}{c}0.132^{* *} \\
(2.09) \\
{[0.02]}\end{array}$ & $\begin{array}{c}0.131^{* *} \\
(2.08) \\
{[0.02]}\end{array}$ & $\begin{array}{l}0.167^{*} \\
(1.57) \\
{[0.00]}\end{array}$ & $\begin{array}{l}0.135 \\
(1.26) \\
{[0.00]}\end{array}$ & $\begin{array}{l}0.132 \\
(1.23) \\
{[0.00]}\end{array}$ & $\begin{array}{l}0.130 \\
(1.21) \\
{[0.00]}\end{array}$ \\
\hline Inward $\operatorname{FDI}_{(t)}$ & $\begin{array}{c}-0.004^{* *} \\
(-2.21) \\
{[0.00]}\end{array}$ & $\begin{array}{c}-0.005^{* * *} \\
(-2.40) \\
{[0.00]}\end{array}$ & $\begin{array}{c}-0.005^{* * *} \\
(-2.40) \\
{[0.00]}\end{array}$ & $\begin{array}{c}-0.005^{* * *} \\
(-2.40) \\
{[0.00]}\end{array}$ & $\begin{array}{c}-0.004 \\
(-0.81) \\
{[0.00]}\end{array}$ & $\begin{array}{c}-0.005 \\
(-1.09) \\
{[0.00]}\end{array}$ & $\begin{array}{c}-0.005 \\
(-1.09) \\
{[0.00]}\end{array}$ & $\begin{array}{c}-0.005 \\
(-1.07) \\
{[0.00]}\end{array}$ \\
\hline $\operatorname{Import}_{(\mathrm{t})}$ & $\begin{array}{c}0.532^{* *} \\
(1.72) \\
{[0.08]}\end{array}$ & $\begin{array}{l}0.421^{*} \\
(1.32) \\
{[0.06]}\end{array}$ & $\begin{array}{l}0.448^{*} \\
(1.42) \\
{[0.07]}\end{array}$ & $\begin{array}{l}0.422^{*} \\
(1.33) \\
{[0.06]}\end{array}$ & $\begin{array}{l}0.123 \\
(0.44) \\
{[0.00]}\end{array}$ & $\begin{array}{c}-0.064 \\
(-0.22) \\
{[0.00]}\end{array}$ & $\begin{array}{l}-0.015 \\
(-0.05) \\
{[0.00]}\end{array}$ & $\begin{array}{l}-0.005 \\
(-0.02) \\
{[0.00]}\end{array}$ \\
\hline Constant $_{(t)}$ & $\begin{array}{c}-3.495^{* * *} \\
(-8.43)\end{array}$ & $\begin{array}{c}-3.785^{* * *} \\
(-8.43)\end{array}$ & $\begin{array}{c}-3.774^{* * *} \\
(-8.47)\end{array}$ & $\begin{array}{c}-3.747^{* * * *} \\
(-8.52)\end{array}$ & $\begin{array}{c}-4.668^{* * * *} \\
(-9.88)\end{array}$ & $\begin{array}{c}-4.759^{* * * *} \\
(-10.01)\end{array}$ & $\begin{array}{c}-4.681^{* * * *} \\
(-9.92)\end{array}$ & $\begin{array}{c}-4.686^{* * *} \\
(-9.92)\end{array}$ \\
\hline Year effects & Included & Included & Included & Included & Included & Included & Included & Included \\
\hline $\mathrm{N}$ & 2118 & 2118 & 2118 & 2118 & 4326 & 4326 & 4326 & 4326 \\
\hline $\begin{array}{c}\text { Log likelihood } \\
-2 \Delta \mathrm{L}\end{array}$ & -1149.153 & $\begin{array}{c}-1147.135 \\
4.036^{* *}\end{array}$ & $\begin{array}{c}-1147.125 \\
4.056^{* *}\end{array}$ & $\begin{array}{c}-1146.818 \\
4.670^{* *}\end{array}$ & -551.905 & $\begin{array}{c}-549.560 \\
4.690^{* *}\end{array}$ & $\begin{array}{c}-550.121 \\
3.568^{*}\end{array}$ & $\begin{array}{c}-550.018 \\
3.774^{*}\end{array}$ \\
\hline
\end{tabular}

$: p<.10 ;{ }^{* * *}: p<.05 ;{ }^{* * * *}: p<.01$ (One-tailed tests)

t-statistics appear in (parentheses); marginal effects in [brackets] 
Table 10. Negative binomial regressions (Split by $R \& D$ ) $\left(\right.$ Dependent variable $=$ Patent applications $\left._{(t)}\right)$

\begin{tabular}{|c|c|c|c|c|c|c|}
\hline \multirow{2}{*}{ Variable } & \multicolumn{3}{|c|}{ Relative Technological Leaders } & \multicolumn{3}{|c|}{ Relative Technological Laggards } \\
\hline & 1 & 2 & 3 & 4 & 5 & 6 \\
\hline Export volume $_{(t-1)}$ & $\begin{array}{c}0.044^{* *} \\
(2.25) \\
{[0.01]}\end{array}$ & & & $\begin{array}{c}0.048^{* *} \\
(1.90) \\
{[0.00]}\end{array}$ & & \\
\hline Export volume $_{(t-2)}$ & & $\begin{array}{c}0.043^{* *} \\
(2.25) \\
{[0.01]}\end{array}$ & & & $\begin{array}{l}0.028 \\
(1.08) \\
{[0.00]}\end{array}$ & \\
\hline Export volume $_{(t-3)}$ & & & $\begin{array}{l}0.040^{* *} \\
(2.15) \\
{[0.01]}\end{array}$ & & & $\begin{array}{l}0.030 \\
(1.17) \\
{[0.00]}\end{array}$ \\
\hline Patent applications $_{(\mathrm{t}-1)}$ & $\begin{array}{c}0.442^{\text {*** }} \\
(6.54) \\
{[0.08]}\end{array}$ & $\begin{array}{c}0.436^{* * *} \\
(6.44) \\
{[0.07]}\end{array}$ & $\begin{array}{c}0.437^{* * *} \\
(6.46) \\
{[0.07]}\end{array}$ & $\begin{array}{c}0.616^{* * *} \\
(3.10) \\
{[0.02]}\end{array}$ & $\begin{array}{c}0.604^{* * *} \\
(3.00) \\
{[0.02]}\end{array}$ & $\begin{array}{c}0.605^{* * *} \\
(3.02) \\
{[0.02]}\end{array}$ \\
\hline Patent applications $_{(t-2)}$ & $\begin{array}{c}0.278^{* * *} \\
(4.24) \\
{[0.05]}\end{array}$ & $\begin{array}{c}0.275^{* * *} \\
(4.24) \\
{[0.05]}\end{array}$ & $\begin{array}{c}0.275^{* * *} \\
(4.24) \\
{[0.05]}\end{array}$ & $\begin{array}{l}0.216 \\
(1.13) \\
{[0.01]}\end{array}$ & $\begin{array}{l}0.225 \\
(1.18) \\
{[0.01]}\end{array}$ & $\begin{array}{l}0.223 \\
(1.17) \\
{[0.01]}\end{array}$ \\
\hline Patent applications $_{(t-3)}$ & $\begin{array}{c}0.098^{* *} \\
(1.82) \\
{[0.02]}\end{array}$ & $\begin{array}{c}0.097^{* *} \\
(1.79) \\
{[0.02]}\end{array}$ & $\begin{array}{c}0.095^{* *} \\
(1.76) \\
{[0.02]}\end{array}$ & $\begin{array}{l}0.031 \\
(0.20) \\
{[0.00]}\end{array}$ & $\begin{array}{l}0.039 \\
(0.24) \\
{[0.00]}\end{array}$ & $\begin{array}{l}0.036 \\
(0.23) \\
{[0.00]}\end{array}$ \\
\hline Advertising intensity $y_{(t)}$ & $\begin{array}{l}0.011 \\
(0.52) \\
{[0.00]}\end{array}$ & $\begin{array}{l}0.012 \\
(0.58) \\
{[0.00]}\end{array}$ & $\begin{array}{l}0.013 \\
(0.59) \\
{[0.00]}\end{array}$ & $\begin{array}{l}0.014 \\
(0.23) \\
{[0.00]}\end{array}$ & $\begin{array}{l}0.017 \\
(0.29) \\
{[0.00]}\end{array}$ & $\begin{array}{l}0.019 \\
(0.31) \\
{[0.00]}\end{array}$ \\
\hline $\operatorname{Size}_{(\mathrm{t})}$ & $\begin{array}{l}0.090^{*} \\
(1.34) \\
{[0.02]}\end{array}$ & $\begin{array}{l}0.092^{*} \\
(1.38) \\
{[0.02]}\end{array}$ & $\begin{array}{l}0.094^{*} \\
(1.41) \\
{[0.02]}\end{array}$ & $\begin{array}{l}0.110 \\
(0.99) \\
{[0.00]}\end{array}$ & $\begin{array}{l}0.137 \\
(1.24) \\
{[0.00]}\end{array}$ & $\begin{array}{l}0.136 \\
(1.23) \\
{[0.00]}\end{array}$ \\
\hline Inward FDI ${ }_{(\mathrm{t})}$ & $\begin{array}{c}-0.005^{* * *} \\
(-2.54) \\
{[0.00]}\end{array}$ & $\begin{array}{c}-0.005^{* * *} \\
(-2.53) \\
{[0.00]}\end{array}$ & $\begin{array}{c}-0.005^{* * *} \\
(-2.50) \\
{[0.00]}\end{array}$ & $\begin{array}{c}-0.006 \\
(-1.19) \\
{[0.00]}\end{array}$ & $\begin{array}{c}-0.005 \\
(-1.05) \\
{[0.00]}\end{array}$ & $\begin{array}{c}-0.005 \\
(-1.04) \\
{[0.00]}\end{array}$ \\
\hline $\operatorname{Import}_{(t)}$ & $\begin{array}{l}0.424^{*} \\
(1.34) \\
{[0.06]}\end{array}$ & $\begin{array}{l}0.443^{*} \\
(1.41) \\
{[0.06]}\end{array}$ & $\begin{array}{l}0.431^{*} \\
(1.36) \\
{[0.06]}\end{array}$ & $\begin{array}{c}-0.021 \\
(-0.07) \\
{[0.00]}\end{array}$ & $\begin{array}{l}0.040 \\
(0.14) \\
{[0.00]}\end{array}$ & $\begin{array}{l}0.038 \\
(0.13) \\
{[0.00]}\end{array}$ \\
\hline Constant $_{(\mathrm{t})}$ & $\begin{array}{c}-3.581^{* * *} \\
(-8.48)\end{array}$ & $\begin{array}{c}-3.574^{* * * *} \\
(-8.50)\end{array}$ & $\begin{array}{c}-3.534^{* * *} \\
(-8.43)\end{array}$ & $\begin{array}{c}-4.650^{* * *} \\
(-9.84)\end{array}$ & $\begin{array}{c}-4.646^{* * *} \\
(-9.82)\end{array}$ & $\begin{array}{c}-4.652^{* * *} \\
(-9.84)\end{array}$ \\
\hline Year effects & Included & Included & Included & Included & Included & Included \\
\hline $\mathrm{N}$ & 2118 & 2118 & 2118 & 4326 & 4326 & 4326 \\
\hline Log likelihood & -1146.645 & -1146.647 & -1146.855 & -550.081 & -551.318 & -551.222 \\
\hline$-2 \Delta \mathrm{L}$ & $5.016^{* *}$ & $5.012^{* *}$ & $4.596^{* *}$ & $3.648^{*}$ & 1.174 & 1.366 \\
\hline
\end{tabular}

${ }^{*}: p<.10 ;{ }^{* * *}: p<.05 ;{ }^{* * *}: p<.01$ (One-tailed tests)

t-statistics appear in (parentheses); marginal effects in [brackets] 